\title{
War Veterans, Demobilization and Political Activism: Greater Romania in Comparison
}

\author{
Constantin Iordachi \\ Central European University, Budapest \\ iordachinnc@ceu.edu \\ Blasco Sciarrino \\ Central European University, Budapest \\ Sciarrino_Blasco@phd.ceu.edu
}

\begin{abstract}
This article aims to further problematize the relationship between patterns of demobilization, fascism and veterans' activism, on several inter-related counts. We argue that the relationship between fascism and war veterans was not a fixed nexus, but the outcome of a complex political constellation of socio-economic and political factors that necessitates a case-by-case in-depth discussion. Also, we argue that these factors were both national and transnational in nature. Finally, we contend that researchers need to employ a synchronic as well as a diachronic perspective, thus accounting for various stages and forms of mobilization of war veterans over time. To substantiate these claims, the current article focuses on a relevant but largely neglected case study: the demobilization of soldiers and war veterans' political activism in interwar Romania. It is argued that, contrary to assumptions in historiography, demobilization in Romania was initially successful. Veterans' mobilization to fascism intensified only in mid-to late 1930s, stimulated by the Great Depression, leading to a growing ideological polarization and the political ascension of the fascist Legion of 'Archangel Michael'. To better grasp the specificities of this case study, the concluding section of the article compares it to patterns of veterans' activism in postwar Italy.
\end{abstract}

\section{Keywords}

Romania - Italy - fascism - First World War - demobilization - war veterans radicalization - Iron Guard

(C) IORDACHI AND SCIARRINO, 2017 | DOI 10.1163/22116257-00601004

This is an open access article distributed under the terms of the Creative Commons Attribution-

Noncommercial 4.0 Unported (CC-BY-NC 4.0) License. http://creativecommons.org/licenses/by-nc/4.0/23 11:38:02PM 
In August 1924, a scuffle took place in the Italian town of Collodi. Local fascists and veterans from the Associazione Nazionale Combattenti [ANC; National Servicemen's Association] had come to blows, after one of the former taunted the latter by yelling: 'What have you fighters actually accomplished? Had it not been for us, you would have been lost. You did not come to the March on Rome!' That squadristi could, on occasion, draw a line between themselves and nationalist former servicemen can be taken as a useful reminder that war veterans were not the only constituency of fascist militias. Nevertheless, for many decades, scholarship was dominated by the view that fascism was the product of war resentment in defeated countries, and that its most important social proponents were the veterans and the insecure petty bourgeoisie. It is only recently that historians have revisited the relationship between interwar fascist paramilitaries and demobilized soldiers, aiming to go beyond the deterministic assumption that the latter were inherently drawn to the militarist ethos and tenets of the former. Following this wave of research, a variegated picture of the fascist constituencies has emerged. A plethora of new works on the topic has pointed out that, although the veterans certainly played an important role in the emergence of fascism, they were not the only and, in some cases, not even the main constituent group of fascist paramilitaries. Since, as a sociological category, the term 'veterans' cuts across a variety of social and cultural identity-markers, historians have to take into account a wider spectrum of political attitudes and forms of activism exhibited by veterans in the interwar period.

In line with this research effort, the current article aims to further problematize the relationship between patterns of demobilization, fascism and veterans' activism, on several inter-related counts. First, we posit that, in spite of the fact that fascism was a European-wide phenomenon, until recently the available literature concentrated preponderantly on Western European cases, leaving aside patterns of postwar mobilization in the eastern part of the continent. In order to fully grasp the complexities of this relationship, scholarship needs to explore a larger range of case studies, situated in the East as well as in the West. Second, we argue that the relationship between fascism and veterans was not a fixed nexus, but the outcome of a complex constellation of socio-economic and political factors. Third, we argue that these factors were both national and transnational in nature; to analyze them, scholars should

1 Report dated 17 September 1924, sent by the prefect of Lucca to the Italian Ministry of Interior, from folder 71 - category G1, for year 1924, in the fund Ministero dell'Interno - Direzione Generale Pubblica Sicurezza, Divisione Affari Generali e Riservati at the Archivio Centrale di Stato, in Rome, 3 . 
combine case-study investigations with the comparative method and the history of transfers. Finally, we contend that, given the fluid, unstable and contextual relationship between fascism and veterans' activism, researchers need to employ a synchronic as well as a diachronic perspective, thus accounting for various stages and forms of mobilization of ex-servicemen over time.

To substantiate these claims, the article focuses on a relevant but largely neglected case study: the demobilization of soldiers and war veterans' political activism in interwar Romania. This case study can provide useful points for comparing the political activism of Great War veterans across Europe, as the Romanian veterans' community was denoted by a largely successful process of economic and political demobilization. ${ }^{2}$ The article is organized in several inter-related parts. The first section reviews the most recent historiographical trends in the field; we then proceed to an analysis of veterans, social politics, and political activism in Greater Romania, ending with a set of comparative conclusions.

\section{Veterans and Fascist Paramilitarism: New Perspectives}

The recent historiographical impulse to re-assess the relationship between Great War servicemen and interwar right-wing militias has stemmed largely, though not exclusively, from debates related to the development of fascism in Italy, Germany, Austria and France. Although there is no consensus among historians in these countries on the causes of veterans' involvement in rightist paramilitarism, a common trend can be delineated, i.e. a tendency to specify the scope of this involvement. Firstly, works on social history have increasingly highlighted the participation of various social groups in fascist militias, emphasizing the fact that former servicemen were not the only prominent activists within these combat units. True, veterans were at the core of early paramilitary mobilizations. Their importance in the early stages is unquestionable, as they socialized the combat groups with training, rituals, symbols and some elements of ideology. Moreover, former fighters played a central role in the Italian Fascist mobilization of the early 1920s. ${ }^{3}$ However, various

2 For Romania's participation to the war effort, see Keith Hitchins, Rumania, 1866-1947 (Oxford: Oxford University Press, 1994), 251-291; Maria Bucur, Heroes and Victims: Remembering War in Twentieth-Century Romania (Indianapolis: Indiana University Press, 2009), 73-97.

3 See Adrian Lyttelton, The Seizure of Power: Fascism in Italy, 1919-1929, 2nd edition (Princeton: Princeton University Press, 1987), 52-76; Marco Revelli, 'Italy', in The Social Bases of European Fascist Movements, ed. Detlef Muhlberger (London: Croom Helm, 1987), 17-25. 
studies have pointed out that right-wing political mobilization in Germany, Austria and France eventually reached beyond veterans. Within these countries fascist movements managed to enrol diverse social categories, so that, in the long run, a considerable part of their paramilitary wings consisted of students, peasants and even workers. ${ }^{4}$ In generational terms, relevant constituents of these militias were the cohorts growing up on the home-front, as well as young men coming of age in the interwar years. ${ }^{5}$ It therefore seems that, on the whole, fascist fighting units were diverse environments, which 'intersected' rather than overlapped with national veterans' communities. This assessment is compounded by the observation that, through the interwar era and World War Two, fascist and parafascist regimes relied on many nonveterans for the organization and implementation of their policies of repression or extermination. ${ }^{6}$

4 On Germany, see Peter H. Merkl, 'Approaches to Political Violence: The Stormtroopers, 1925-1933,' in Social Protest, Violence and Terror in Nineteenth- and Twentieth-Century Europe, ed. Wolfgang J. Mommsen and Gerhard Hirschfeld (London: Macmillan, 1982), 379; Detlef Muhlberger, Hitler's Followers (London: Routledge, 1991), 159-180. On Austria, see Gerhard Botz, 'Political Violence, its Forms and Strategies in the First Austrian Republic,' in Social Protest, Violence and Terror in Nineteenth- and Twentieth-Century Europe, ed. Wolfgang J. Mommsen and Gerhard Hirschfeld (London: Macmillan, 1982), 310, 317-322; Michael Mann, Fascists (Cambridge: Cambridge University Press, 2004), 216-224. On France, see Robert Soucy: 'French Fascism and the Croix de Feu: A Dissenting Interpretation,' Journal of Contemporary History 26 (1991): 159; Robert Soucy, French Fascism: The Second Wave, 1933-1939 (New Haven: Yale University Press, 1995), 128-136.

5 On Italy, see Roberta Suzzi Valli, 'The Myth of Squadrismo in the Fascist Regime,' Journal of Contemporary History 35, no. 2 (2000): 135-136; Mimmo Franzinelli, Squadristi: Protagonisti e Tecniche della Violenza Fascista (Milano: Mondadori, 2003), 34-57. On Germany, Sven Reichardt, Faschistische Kampfbunde: Gewalt und Gemeinschaft im Italienischen Squadrismus und in der Deutschen sA (Koln: Bohlau Verlag, 2002), 346-386; Benjamin Ziemann, Rural Experiences in Northern Germany, 1914-1923 (Oxford: Berg, 2007), 6-7. On Austria, Mann, Fascists, 213; Robert Gerwarth and John Horne, 'Vectors of Violence: Paramilitarism in Europe after the Great War, 1917-1923,' The Journal of Modern History 83 (2011), 498-503. On France, Sean Kennedy, Reconciling France against Democracy: The Croix de Feu and the Parti Social Francais, 1927-1945 (Sabon: McGill-Queen's University Press, 2007), 88, 103106; Samuel Kalman, The Extreme Right in Interwar France (Burlington: Ashgate, 2008), 158-179.

6 On Italy, see Dianella Gagliani, Brigate Nere: Mussolini e la Militarizzazione del Partito Fascista Repubblicano (Torino: Bollati Boringhieri, 1999), 168-182. On Germany and Austria, Peter H. Merkl, Political Violence under the Swastika: 581 Early Nazis (Princeton: Princeton University Press, 1975), 638-716; Michael Mann, The Dark Side of Democracy: Explaining Ethnic 
Secondly, historians have gradually stressed the conjunctural nature of the relation between veterans and fascism. Generalizing, it can be said that increasing attention is being paid to how, in each country, this relation was enabled by several, concomitant causes. In doing so, recent analyses attempt to integrate the observation of institutional, cultural and economic factors. Furthermore, emphasis is placed on the contingencies that made the overlap between these various circumstances possible rather than on 'immutable' causes.

Above all, these approaches provide relevant contributions to the prolific debate on the motivations leading to former servicemen's radicalization to fascism, which has often been denoted by widely divergent views. Summing up the numerous readings on the issue, historians at first emphasized short- or long-term economic causes, relating chiefly to the veterans' wish to preserve their social status or overcome deprivation. For example, Italian army officers operating in the Fasci di combattimento [Fighting Fasces] aimed at protecting their class interests, while those who had been demobilized looked for a new way to make a living in the postwar context. ${ }^{7}$ The Heimwehr [Home Guard] in Austria and Freikorps [Free Corps] in Germany mobilized against the prosocialist status quo of the early postwar years. ${ }^{8}$ Rohm's sA [Storm Detachment] catered to unemployed 'military desperadoes' ${ }^{9}$ while middle-class anciens combattants joined the liguées out of economic conservatism. ${ }^{10}$

Scholars have also explored the political and cultural processes that affected patterns of veterans' mobilization in the interwar period. Early interpretations asserted that the postwar behavior of the veterans depended on the general features of 'national political cultures', being influenced by the deep-seated 'militarist traditions' of their nation's political life. ${ }^{11}$ Hence German Kampfer adhered to Nazi paramilitarism, but French combattants stayed aloof from the Faisceau [Fascis] and the Croix de Feu [Fire Cross] due to their

Cleansing (New York: Cambridge University Press, 2005), 223-228, 234-239, 276-278. On France, Robert Paxton, Vichy France: Old Guard and New Order, 1940-1944 (New York: Columbia University Press, 1982), 250-254.

7 Gaetano Salvemini, The Origins of Fascism in Italy (New York: Harper Torchbook, 1973), 119-136, 316-329.

8 Francis Ludwig Carsten, The Rise of Fascism (London: Methuen, 1967), 223-229.

9 Wolfgang Sauer, 'National Socialism: Totalitarianism or Fascism?' The American Historical Review 73 (December 1967): 411-422.

10 Robert Soucy, 'France: Veterans' Politics between the Wars,' in The War Generation, ed. Stephen R. Ward (New York: Kennikat Press, 1975), 71-72, 90.

11 Antoine Prost, 'The Impact of War on French and German Political Cultures,' The Historical Journal 37, no. 1 (1994): 211-215. 
country's democratic tradition..$^{12}$ Gradually, however, historians have employed a less deterministic approach and focused on contingent wartime and postwar developments in each nation. In a pioneering work, Mosse underscored the impact of the Great War, claiming that German soldiers adhered to fascism's cult of activism as it legitimized an attitude they had developed at the front: a heightened indifference to taking human lives in order to solve political problems. ${ }^{13}$ His hypothesis, that servicemen became fascists out of the aforementioned wartime 'brutalization', has also been applied to Italy, France and Austria, but has been met with well-founded criticisms, chiefly the lack of 'brutalized' behavior among the majority of former combatants. ${ }^{14}$ This theory has consequently failed to provide a common framework for explaining veterans' extremism at European level.

More convincing in this regard have been subsequent approaches based on the 'cultural demobilization' interpretation. ${ }^{15}$ These explore the incentives and limitations regarding violence that veterans met in the various postwar national realities, and how these possibilities and constraints interacted with

12 Antoine Prost, Les Anciens Combattants et la Société Francaise, 1914-1939: Mentalites et Ideologies (Paris: Presses de la Fondation Nationale des Sciences Politiques, 1977), 121-151, 217-223.

13 George Mosse, Fallen Soldiers: Reshaping the Memory of the World Wars (New York: Oxford University Press, 1991), 159-181.

14 For cases made against Mosse's ‘brutalization' theory, see Lorenzo Benadusi, 'Borghesi in Uniform: Masculinity, Militarism and the Brutalization of Politics from the First World War to the Rise of Fascism,' in In the Society of Fascists: Acclamation, Acquiescence and Agency in Mussolini's Italy, ed. Giulia Albanese and Roberta Pergher (New York: Palgrave Macmillan, 2012), 35-45; Richard Bessel, Germany after the First World War (New York: Oxford University Press, 1993), 254-274; Benjamin Ziemann, 'Germany after the First World War: A Violent Society? Results and Implications of Recent Research on Weimar Germany,' Journal of Modern European History 1 (2003): 81-95; Antoine Prost, 'Les Limites de la Brutalisation: Tuer sur le Front Occidental, 1914-1918,' Vingtième Siècle 81, no. 1 (2004): 8-20. For a qualified endorsement of the theory, see Angelo Ventrone, 'Fascism and the Legacy of the Great War,' in The Legacies of Two World Wars: European Societies in the Twentieth Century, ed. Lothar Kettenacker and Torsten Riotte (New York: Berghahn, 2011), 96-97.

15 A process of cultural demobilization contains several distinctive features: 'Dismantling the enemy, restoring his humanity and meeting him as an equal ... renewing the international communities that (have) been shattered by the war ... (addressing) the pivotal role of the soldier's wartime sacrifice ... reversing wartime understandings of the conflict (thereby making) the war strangely incomprehensible,' see John Horne, 'Demobilizing the Mind: France and the Legacy of the Great War, 1919-1939,' French History and Civilization 2 (2009): 111-115. 
wartime cultural processes. Such approaches posit that all combatant societies developed similar Manichean cultural frameworks, also known as 'cultures of war, ${ }^{\prime} 6$ to reinforce wartime mobilization. Accordingly, defeat in the conflict should be considered the main trigger for veterans' interwar violence as, in the countries on the losing side, cultures of war survived as 'cultures of defeat' and continued to influence servicemen after they returned home. Their former targets during wartime were rebranded as 'inner enemies' in postwar times and consequently veterans' paramilitarism should be understood as a radical form of political militancy, aimed at preserving their nation and sheltering it from further defeat. ${ }^{17}$ Conversely, countries on the winning side underwent a process of cultural demobilization thanks to the stabilizing effect of victory: here cultures of war gave way to 'cultures of victory',18 thereby ensuring a significantly lower level of violent activism on behalf of former combatants.

The most recent iterations of this theory, on the other hand, stress that processes of cultural demobilization were affected more by the endurance of wartime political and social strains within postwar societies, than by defeat or victory per se. Thus, the failed demobilization of veterans in Italy, Germany and Austria is ascribed mainly to interwar developments, chiefly the state's failure to preserve its monopoly of violence ${ }^{19}$ and create a widely accepted narrative of wartime sacrifice. ${ }^{20}$ Additionally, it has been posited that fears of defeat

16 John Horne, 'Introduction: Mobilizing for “Total War", 1914-1918,' in State, Society and Mobilization in Europe during the First World War, ed. John Horne (Cambridge: Cambridge University Press, 1997), 1-17; John Horne, 'Introduction,' 14-18 Aujord'hui-Today - Heute 5 (2002): 45-53.

17 Wolfgang Schivelbusch, Die Kultur der Niederlage: Der amerikanische Sueden 1865, Frankreich 1871, Deutschland 1918 (Berlin: Alexander Fest Verlag, 2001), 15-49, 242-294.

18 John Horne, 'Defending Victory: Paramilitary Politics in France, 1918-1926: A CounterExample,' in War in Peace: Paramilitary Violence in Europe after the Great War, ed. Robert Gerwarth and John Horne (Oxford: Oxford University Press, 2013), 218.

19 Robert Gerwarth and John Horne, 'Paramilitarism in Europe after the Great War: an Introduction,' in War in Peace: Paramilitary Violence in Europe after the Great War, ed. Robert Gerwarth and John Horne (Oxford: Oxford University Press, 2013), 7-18; Robert Gerwarth and John Horne, 'Bolshevism as Fantasy: Fear of Revolution and Counterrevolutionary Violence, 1917-1923,' in War in Peace, 42-54; Robert Gerwarth, 'Fighting the Red Beast: Counterrevolutionary Violence in the Defeated States of Central Europe,' in War in Peace, 52-68; Emilio Gentile, 'Paramilitary Violence in Italy: The Rationale of Fascism and the Origins of Totalitarianism,' in War in Peace, 88-98.

20 On Italy, see Wanda Wilcox, 'From Heroic Defeat to Mutilated Victory: The Myth of Caporetto in Fascist Italy', in Defeat and Memory: Cultural Histories of Military Defeat in the Modern Era, ed. Jenny Macleod (New York: Palgrave Macmillan, 2008), 49-53; John Horne, 
lingered within veterans even in established cultures of victory, as in France. True, anciens combattants underwent cultural demobilization with regard to one wartime foe, Germany, thanks to victory on the battlefield and, later on, Briand's pursuit of reconciliation between the two countries. No comparable demobilization occurred, however, with respect to another Great War enemy, Soviet Russia of 1917-18. Throughout the interwar years conservative and fascist veterans viewed the local communists as Bolshevik 'fifth columns', bent on undermining the patrie from within, just as they had allegedly attempted to do in the final stages of the Great War. As Chris Millington points out, due to this incomplete demobilization, many combattants would have been ready to radicalize in a paramilitary direction, had they not been assuaged in their concerns and discouraged from taking up arms by the resilient French State. ${ }^{21}$ Millington's assertion that even in France cultural demobilization remained incomplete problematizes the notion of 'cultures of victories' across interwar Europe, arguably positing that the moderation of old soldiers depended on an enduring State monopoly on coercion.

Recent perspectives on the connection between veterans and fascist paramilitarism contribute to the aforementioned debate by adopting a more unified approach. They frame the political violence enacted by fascist veterans as the result of a cluster of interrelated circumstances, which developed mainly in the postwar era. The most relevant among these circumstances are held to be the state's failure to accomplish the demobilization of veterans, through material and symbolic integration, and uphold its monopoly of violence by preserving an efficient coercion apparatus, but also projecting credible notions of order through the figurative resources at its disposal. These innovative viewpoints hence suggest that widespread veterans' violence resulted from policy failure both in the realm of economic and cultural re-integration. Accordingly,

'Beyond Cultures of Victory and Defeat? Inter-War Veterans' Internationalism,' in The Great War and Veterans' Internationalism, ed. Julia Eichenberg and John Paul Newman (New York: Palgrave Macmillan, 2013), 219-220. On Germany, see Benjamin Ziemann, Contested Commemorations: Republican War Veterans and Weimar Political Culture (New York: Cambridge University Press, 2013), 274-279. On Austria, Catherine Edgecombe and Maureen Healy, 'Competing Interpretations of Sacrifice in the Postwar Austrian Republic,' in Sacrifice and Rebirth: The Legacy of the Last Habsburg War, ed. Mark Cornwall and John Paul Newman (New York: Berghahn, 2016), 15-34.

21 Chris Millington, From Victory to Vichy: Veterans in Interwar France (Manchester: Manchester University Press, 2012), 13-15; Brian Jenkins and Chris Millington, France and Fascism: February 1934 and the Dynamics of Political Crisis (New York: Routledge, 2015), 149-171. 
they advocate an integrated analysis of state policymaking towards veterans, through a synchronic focus on deterrence tactics, welfare provisions and politics of symbols, especially when studying the crucial phase of transition from war to peace. ${ }^{22}$

It should be stressed that such approaches downsize the qualitative connection between demobilized soldiers and fascist militias. They posit that the far Right made significant inroads within national communities of old soldiers only in those cases in which the state failed to satisfy veterans in most of their requests and, conversely, fascism managed to pose as the most effective alternative for the fulfilment of these demands. Moreover, it is emphasized that the potential convergence between the two groups depended on the stability of the political system, both real and perceived. In cases where the state did not experience a breakdown of authority, as in France or in the early Weimar republic, veterans did not switch en masse to fascism.

Ultimately, therefore, recent interpretations are useful for reassessing the determinist link, between veterans and the extreme Right, that has been established by early scholarship on the topic. Additionally, they help restore agency to the activism of former fighters, as they arguably make the case that these paramilitaries' behavior was more rational - no matter how vicious - than allowed for by Mosse's battlefield brutalization hypothesis.

Most intriguingly, these new trends contribute to assessing more clearly the impact of cultures of war on the violence of Great War fighters in the interwar years. Specifically, they highlight that, while similar cultures of war were developed by all combatant societies, a different array of influences shaped each one of these cultures after the conflict. This assumption helps set the stage for comparative and connective analyses of how wartime mentalities changed under the influence of a variety of postwar national and transnational factors. The challenge is being taken up by scholars who, by comparing and connecting Italy, Germany, Austria and France to other former combatant states, aim at answering relevant questions such as to what extent did cultures of victory moderate old soldiers, and what institutional and social checks did cultures of defeat encounter in interwar political realities.

Ultimately, therefore, these new approaches to the study of fascist paramilitarism provide new avenues of research also on Central and South-Eastern Europe, two historical regions that received comparatively less scholarly

22 See Mark Edele and Robert Gerwarth, "The Limits of Demobilization: Global Perspectives on the Aftermath of the Great War,' Journal of Contemporary History 50 (2015): 7-12. 
attention. ${ }^{23}$ They underscore the fact that, in their assessment of the political violence enacted by the members of right-wing fighting organizations, scholars should blend the observation of institutional, cultural and economic factors. Special attention should be paid to how wartime cultural frameworks interacted with postwar political and social realities, both endogenous and exogenous to national case studies.

\section{Veterans and Politics in Romania, 1878-1913}

From a legal point of view, the category of 'war veteran' was a relatively late development in modern Romania, its emergence being intimately linked to the recreation of the national army and the country's fight for independence. In the Middle Ages, the Principalities of Moldavia and Wallachia had large feudal armies; the aggravation of the regime of Ottoman domination in the seventeenth century led to the abolition of these armies, apart from small princely guards. In both Principalities, new armies were established in 1831, under the new Organic Regulations, and unified in a single national army in 1859, after the union of Moldavia and Wallachia. ${ }^{24}$ In 1878 , Romania proclaimed its state independence following its participation to the $1877^{-1878}$ Russian-Ottoman war. The Romanian army mobilized 58,700 soldiers in the military campaign against the Ottoman Empire, led on the battlefield by the young prince Carol I; circa 10,000 soldiers lost their lives. The war of independence was subsequently

23 Julia Eichenberg, 'Polish Eagles and Peace Doves: Polish Veterans between Nationalism and Internationalism,' in The Great War and Veterans' Internationalism, ed. Julia Eichenberg and John Paul Newman (New York: Palgrave Macmillan, 2013), 89-9o; John Paul Newman, 'Allied Yugoslavia: Serbian Great War Veterans and their Internationalist Ties,' in The Great War and Veterans' Internationalism, 98-99; Natali Stegmann, 'Social Benefits and the Rhetoric of Peace in Czechoslovak Veteran Organizations,' in The Great War and Veterans' Internationalism, 131-133; John Paul Newman, Yugoslavia in the Shadow of War: Veterans and the Limits of State-Building, 1903-1945 (Cambridge: Cambridge University Press, 2015), 36-52, 147-183, 213-232; Jochen Bohler, 'Enduring Struggle: The Postwar Struggles in East-Central Europe, 1917-21,' Journal of Contemporary History $5^{\circ}$ (2015): 73-76; Mark Cornwall, 'A Conflicted and Divided Habsburg Memory,' in Sacrifice and Rebirth: The Legacy of the Last Habsburg War, ed. Mark Cornwall and John Paul Newman (New York: Berghahn, 2016), 3-10.

24 For the role of the army in the process of national regeneration and its connection with fascism paramilitarism, see Constantin Iordachi, 'God's Chosen Warriors: Romantic Palingenesis, Militarism and Fascism in Modern Romania,' in Comparative Fascist Studies: New Perspectives, ed. Constantin Iordachi (London: Routledge: 2009), 316-357. 
glorified in Romanian politics and cultural life as a historical landmark; in 1881, Carol I was crowned King of the newly proclaimed Kingdom of Romania; his crown was manufactured from Ottoman cannons captured on the battlefield. The cult of the fallen soldier became the central axis of the process of sacralizing politics in modern Romania, being celebrated by an impressive array of monuments, state-sponsored commemorations, and publications cultivating the values of heroism, sacrifice for the fatherland, and loyalty to the dynasty. In addition to symbolic-ideological rewards and recognition, former war combatants were also granted tangible material benefits. A royal decree adopted on 29 April 1902, on the twenty-fifth anniversary of the war of independence, pledged: 'each veteran soldier [ostaş veteran] will be provided with necessary means of existence in order to guarantee his tranquility and occupations for the rest of his life, as a stimulus for the new generations. ${ }^{25}$ To this end, a new law, passed on 2 April 1903, sold landless war veterans, at preferential prices, parcels of eight hectares of land in the province of Dobrudja, annexed by Romania in 1878 by a decision of the Treaty of Berlin. In order to facilitate their colonization of the new province, the law granted veterans agricultural inventory as well as tax exemption for five years, but tied them to the land, expressly demanding that they personally cultivate the land for a grace period of thirty years. The law was only partially successful: although 6,171 families of veterans from all over the country applied for land in Dobrudja, the state was only able to award land to 3,171 families, who settled mostly at the border with Bulgaria and Russia. In practice, however, only 922 families settled effectively in Dobrudja. ${ }^{26}$

The bulk of the veterans protested the law's stipulations, however, demanding land in Romania 'proper'. The situation led to a mobilization of the veterans, led by the Society of Veterans of Lower Military Grades Coroana de Oțel [The Steel Crown] established on 2 February 1903. To lobby for the law's modification, the organization planned a congress and a public demonstration in Bucharest on the day of the Monarchy Day on 10 May 1903, which coincided with the twenty-sixth anniversary of the proclamation of independence. The gendarmerie and the police prevented the veterans from gathering in Bucharest to demonstrate. ${ }^{27}$ In reaction, the political opposition, led by the socialists,

25 Asociația Națională a Veteranilor de Război, 'Istoric Veteran de război,' accessed April 19, 2017, http://www.veterani-ww2.ro/istoric.html.

26 Ioan N. Roman, Studiu asupra proprietatȩi rurale din Dobrogea urmat de Codul proprietătȩi fonciare Otomane din 1858 si de legile Romînesţi referitoare la proprietatea imobiliară rurală din Dobrogea (Constanța: Ovidiu, 1907) 144-145.

27 X.Y.Z., 'Goana contra veteranilor,' Adevărul Xvi (11 May 1903) 4949, 1. 


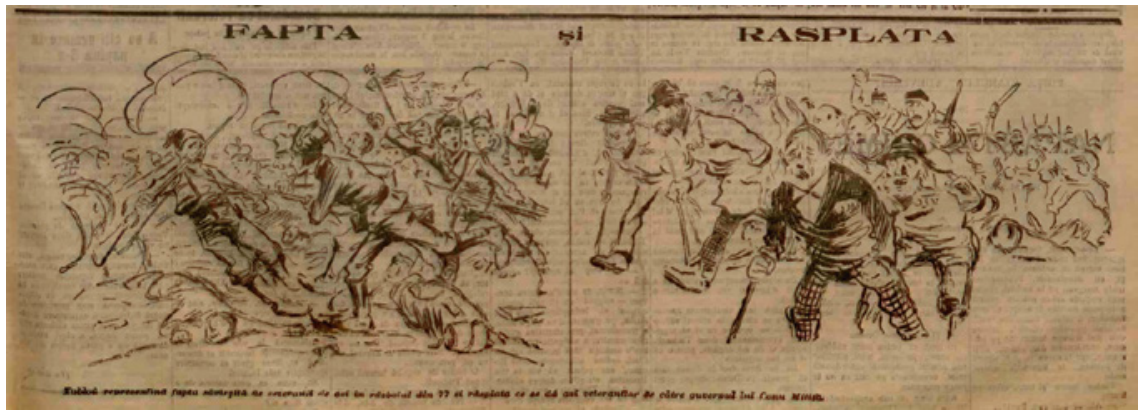

ILLUSTRATION 1

Caricature denouncing the dispersion of the veterans' demonstration. Under the title DEEDS and REWARD, the caption read: 'Tableau depicting the deeds of the veterans in the war of independence and the reward granted to them by the government.

SOURCE: ADEVĂRUL, XVI (11 MAY 1903) 4949, 1.

criticized the government for humiliating 'the saint veterans of the war of independence. ${ }^{28}$ The champion of this campaign was the socialist deputy Constantin Mille, the director of the newspaper Adevărul, who collected petitions on behalf of the war veterans demanding a new land reform. The politicization of this incident gave birth to a 'veterans' question' in modern Romania, intimately linked to the larger agrarian question.

The failure of that action led to a split in the veterans' representation. On 1 June 1903, a new, more militant society of war veterans was created, called Crucea Trecerea Dunării [The Cross-Going Across the Danube], with its seat in Bucharest. The new society aimed at improving the material situation of the veterans by obtaining old-age pensions and other facilities from the state, at enhancing their societal recognition and prestige, at promoting solidarity ties among the veterans, and at organizing forms of mutual help for veterans and their descendants. Following the political lobbying of the two organizations, in November 1903 a delegation of veterans met the liberal Prime Minister Dimitrie Sturza (27 February 1901 - 4 January 1906) and obtained a firm promise that landless veterans would be granted five hectares of land in Romania 'proper.'29

This pledge renewed the bonds between the veterans and the dynasty. Veteran representatives thus figured predominantly during the lavish celebrations

28 Constantin Mille, '1o maiu și veteranii,' Adevărul Xvi (11 May 1903) 4949, 1.

29 R.P. 'Veteranii la Consiliul de Miniștrii,' Adevărul Xvi (12 November 1903) 5133, 1. 
that took place on the fortieth anniversary of the monarchy and the twentyfifth anniversary of the coronation in May 1906. ${ }^{30}$ During the official ceremony, a company of veterans of the war of independence carried the historical flags of the war of independence from the Throne Hall to the Metropolitan Church for a solemn Te-Deum. Officers as well as rank-and-file veterans were integrated into the official military parade accompanying the king to his palace. ${ }^{31} \mathrm{In}$ the evening, the monarch organized a festive dinner for six hundred veterans, presided by the Ministry of War, Constantin Manu. ${ }^{32}$ Finally, on 27 May 1903 King Carol I welcomed a delegation of The Steel Crown organization. Official press reports emphasized the fact that the monarch listened carefully to the veterans' griefs; they also reiterated the strong bonds between the hero-king (himself a former combatant in the war of independence) and 'his veterans'.

These ceremonies and the symbolic-ideological bond between the monarch and the veterans did not alleviate social tensions, however. The peasantveterans' social question was an integral part of a larger agrarian question. The pressure for land and the deterioration of the status of the country's sharecropping peasantry were to lead to a major peasant uprising in 1907, the last 'modern Jacquerie' in Europe, marked by open confrontations between peasants and the army. ${ }^{33}$

After a harsh military repression of the revolt, authorities took several steps meant to improve the situation of landless peasantry. In this context, veterans intensified their lobbying for land awards. Similarly to former soldiers of lower ranks, veteran officers organized themselves as well, forming two separate corporate organizations called Virtutea Militară [Military Virtue], established in May 1905, and Societatea 'Ofițerii Veterani' [Society of Veteran Officers], created in October $1906 .{ }^{34}$ In May 1907, the two societies merged into a single Societatea 'Ofițerii Veterani' 'Virtutea Militară' [Society of the 'Veteran Officers' 'Military Virtue'], recognized as a juridical entity by the parliament in March $1910 .^{35}$ This process of unification took place among the veterans of the lower ranks, too: The Cross-Going Across the Danube managed to impose itself as the main representative of veterans' interests, so that on 1 September 1910 the

\footnotetext{
30 Amintiri despre jubileul de 40 de ani de domnie a M. S. Regelui Carol I: 1866-19o6 (Bucureşti: Imprimeria Statului, 1906).

$31 \quad$ Amintiri desprejubileul, 37-38.

32 Amintiri desprejubileul, 42.

33 Philip G. Edelberg, The Great Rumanian Peasant Revolt of 19o7: Origins of a Modern Jacquerie (Leiden: Brill, 1974).

34 Monitorul oficial (29 July-11 August 1911), no. 94, 4544.

35 Monitorul oficial, no. 94 (29 July-11 August 1911), 4544.
} 
Steel Crown fused with it. In 1911, the unified organization had $5^{26}$ members and a capital of 7,824.65 lei. ${ }^{36}$ In December 1911, the Cross was recognized as a legal entity representing the veterans of lower ranks by the parliament. ${ }^{37}$ In the same session, the parliament approved additional facilities for the veterans, such as the abolition of the pension tax of $10 \%$ for the veteran officers who 'participated in the campaign across the Danube or served on the bank of the river' (applied from 1 April 1912), and their descendants. ${ }^{38}$ Most importantly, following on the 1906 governmental pledge, a new 'Law on selling state land in small and large plots' adopted on 18 March 1912, granted landless war veterans privileged access to land sold by the state, ahead of all other categories of landless peasants. ${ }^{39}$ This law was a clear indication that participation to war was a privileged avenue of social emancipation for the pauper peasantry. At official level, it showed the monarch's interest to appear as a protector of the veterans' organizations; this alliance led to the gradual emergence of a certain 'culture of entitlement' on the veterans' side, supported by the monarch.

Numerically, the category of war veterans expanded after Romania's participation in the Second Balkan War. On 10 July 1913 amid heavy fighting between the Bulgarian and the Serbian armies, Romania attacked Bulgaria and annexed Southern Dobrudja. Although the Romanian army was not involved in direct combat, the war had a strong societal impact. During their incursion into Bulgarian territory, Romanian peasant-soldiers could compare their destitute social situation to the relatively affluent status of the peasantry in north-eastern Bulgaria. The war experience thus boosted the peasants' claims for agrarian and electoral reforms, a desideratum that was to be fulfilled during the Great War. ${ }^{40}$

\section{From War to Peacetime: The Demobilization of Veterans in Greater Romania}

Less than a year after the end of the Second Balkan War, the region was subject to yet another war, which degenerated into a global conflagration. Romania's participation to the Great War had a peculiar timing (1916-1919), in tune with

\footnotetext{
$36 \quad$ Dezbaterile Adunării Deputaților, no. 16 (23 December 1911), 299.

37 Ibidem, 299 .

38 Ibidem, 268-269.

39 See also the Regulations of the Ministry of Agriculture and Domains, in Monitorul Oficial, 168 (26 October-6 November 1913), 7060-7065.

40 On this issue, see Nicolae Iorga, Acțunea militară a României: În Bulgaria cu oștașii noștrii (Vălenii-de-Munte: Neamul Românesc, 1913).
} 
the geopolitical realities of Central and South-Eastern Europe. First, the country entered the war only on 25 August 1916, after two years of arduous diplomatic negotiations with the Entente, with a military action against Austria-Hungary in Transylvania, Second, Romania's military campaign ended earlier, the defection of Russia on the Eastern Front forcing Romania to sign a separate Peace Treaty with the Central Powers at Bucharest on 7 May 1918. Third, Romania's military effort continued well after the Great War: the country resumed military operations against the Central Powers on 10 November 1918, and in April to August 1919 engaged in a war against the Hungarian Soviet Republic led by Béla Kun, that ended with the occupation of Budapest.

While Romania's military campaign during the Great War might thus appear short (August 1916-December 1917), its history of military mobilization was in fact quite long, starting as it was with the Second Balkan War in 1913 and ending with the withdrawal of its occupational troops from Hungary in June 1920. Surely, military mobilization was not continuous during this long period, but was characterized by waves of mobilization and (partial) demobilization. Between 1913-1916, the Old Kingdom of Romania intensified its war preparations, managing to enlarge its active and reserve army to a share of $15 \%$ of the population, while its officer corps grew from 8,200 officers to $20,000 .{ }^{41}$ In 1916, Romania mobilized 813,758 soldiers, led by 20,000 officers, making up $11 \%$ of the country's population. This active army was supplemented by a reserve force of 416,0oo men, including the 1917 cohort of recruits, youngsters between eighteen and twenty-six years old, and other types of reserve combatants. ${ }^{42}$ Under the May 1918 Treaty of Bucharest signed with the Central Powers, Romania was forced to partially demobilize its army 'on a reduced peace footing. ${ }^{43}$ Although its general terms were highly onerous for Romania, the Treaty assured, nevertheless, the preservation of the Romanian army. These troops were instrumental in securing the union of Bessarabia to Romania in April 1918, neutralizing defective Russian soldiers and deterring an imminent attack from Soviet Russia. On 10 November 1918 - one day before the end of World War I - Romania remobilized its active army, supplemented with new cohorts and with war veterans from its newly acquired territories, and was thus

41 Constantin Kiritescu, Istoria Războiului pentru întregirea României: 1916-1919, Volume I (Bucureşti: Institututul de Arte Grafice, 1922), 109.

42 Kiritescu, Istoria Războiului, 109.

43 See 'The Treaty of Peace between Roumania and the Central Powers, signed at Bucharest, 7 May 1918,' esp. arts. III-IV, in United States, Department of State, Texts of the Roumanian 'Peace' (Washington, DC: United States Government Printing Office, 1918), 5-28, accessed April 19, 2017, https://www.mtholyoke.edu/acad/intrel/routreat.html. 
able to wage a successful campaign against the Bolshevik regime of Béla Kun in Hungary.

As in other European countries, the Great War had a tremendous impact on Romanian society and politics, in terms of human suffering, material destruction caused by the military campaigns and years of foreign occupation, and socio-political upheaval. During the course of the war, Romania lost 335,000 soldiers (dead or missing) together with 650,00o dead civilians, while 75,491 soldiers became war invalids. ${ }^{44}$ Yet, unlike in other former combatant countries, Romanian veterans did not play a major political role in the immediate postwar period, as a collective actor, and did not undergo a process of rapid and extensive radicalization to fascism. This smooth demobilization might come as a surprise if one considers that, less than a decade earlier, the country's socio-political order was shaken to the core by a series of peasant revolts $(1888,1907)$. Several years later, the mass mobilization of peasants in arms during the Second Balkan War must have given cold shivers to Conservative politicians. In November 1913, soon after the Balkan Wars, the Liberal Party announced publicly its determination to implement comprehensive agrarian and electoral reforms. ${ }^{45}$ Due to the outbreak of World War I, these political decisions could not be translated into laws by the parliament, but their necessity was reiterated by King Ferdinand in December 1916. After the bourgeoisdemocratic revolution that took place in Russia in February 1917, in March/ April 1917 King Ferdinand visited the troops on the front line. To ensure the continued loyalty of soldiers, the king solemnly pledged to grant land and voting rights to peasants: 'To you, sons of peasants, who defended with your arm the land where you were born and raised, I tell you as your King, that in addition to victory as your great reward, you have also earned the right to possess to a larger extent the land for which you fought. You will be granted land. I, your King, will be the first one to set the example; you will also be granted the right to participate more largely to the administration of the state. 46 Although the two reforms were implemented only after the Great War, the King's solemn promises gave peasant-soldiers a cause to fight for, thus adding social incentives to the intense cultural campaign of mobilization for the national cause. Without doubt, victory in the war, the achievement of national unification,

44 Asociația Națională a Veteranilor de Război, 'Istoric Veteran de război', accessed April 19, 2017, http://www.veterani-ww2.ro/istoric.html.

45 Colegiul Unic şi Exproprierea: Marea Întrunire Liberală dela Focşani, ţinută în ziua de 8 Noembre 1913 (Bucureşti: Imprimeriile Independenţa, 1913).

46 'Romania,' (28 March 1917), cited in Ioan Scurtu, Ferdinand I (București: Editura Enciclopedică, 2004), 37, translation C. Iordachi, our emphasis. 
and the postwar implementation of the land reform and the enlargement of political rights, provided immediate solutions - albeit arguably still partial - to the pressing social/political questions of the day, paving the way toward the peaceful demobilization of soldiers.

In addition to these 'positive' factors, there were also 'negative' factors that hampered veterans' political activism. First, Romania's prolonged war effort explains, at least in part, the lack of collective mobilization of veterans. Thus, while in Western Europe demobilized soldiers faced the 'chaotic' immediate postwar situation, Romanian soldiers were remobilized in November 1918 for a new military campaign that lasted until 1920 . When soldiers were finally released from service, the political situation of the country was already 'normalized', the economy by and large stabilized, and the Bolshevik danger largely 'contained', inside as well as outside the country. Second, it should be taken into account that, given the complex regional composition of Greater Romania, the heterogeneous category of war veterans was divided along regional and ethno-linguistic lines. Thus, while soldiers in the Old Kingdom fought the Central Powers in Dobrudja and Transylvania, soldiers recruited in the former Russian province of Bessarabia fought in the Tsar's army, and the soldiers recruited in Transylvania and the Banat fought in the service of the King and Emperor of Austria-Hungary, Franz Joseph. While, from a legal point of view, all war dead and their cemeteries were given equal respect and protection, the official discourse was nevertheless centered on the victory of the Old Kingdom's army in the war, and thus privileged the combatants who contributed to the war of national unification, either as soldiers or as volunteers. At the same time, the experiences of those who fought on the Habsburg, Hungarian or Bulgarian sides (often directly opposing the Romanian army), were in many ways marginalized. ${ }^{47}$ The fragmented and even antagonistic nature of the war experiences of former soldiers prevented their political alliance at national level, resulting in the organizational division of war veterans in various groupings. Other factors that hindered the veterans' political activism were the rural origin of the overwhelming majority of servicemen, which accounts for their dispersion in the countryside after demobilization, ${ }^{48}$ the traditional close association between monarchy and veteran associations, which tempered their

47 For other examples, see John Horne, 'Defending Victory,' 216-234; Julia Eichenberg and John Paul Newman, 'Introduction,' in The Great War and Veterans' Internationalism, ed. Julia Eichenberg and John Paul Newman (New York: Palgrave Macmillan, 2013), 12.

48 Dylan Riley, The Civic Foundations of Fascism: Italy, Spain and Romania 1870-1945 (Baltimore: The Johns Hopkins University Press, 2010), 113-149. 
radicalism, and the state's firm control over protest movements and civil associations in the immediate postwar period.

\section{Politics, Social Protection, and Veterans' Activism: The 1920s}

Ex-servicemen started to organize themselves in Romania soon after their demobilization in 1920. As in the prewar period, war veterans clustered in several category associations according to their military rank, the campaign they fought in, or the nature of their specific grievances. Among them, the most important were: Societatea Mărășești [The Mărășești Society] founded in 1921, and made up of invalids, orphans and widows from the 1913 campaign and the Great War; ${ }^{49}$ Uniunea Națională a Foștilor Luptători [The National Association of Former Combatants], founded in early 1920, and led by Reserve Captain Virgiliu Serdaru; ${ }^{50}$ Asociatia Subofițerilor Pensionari din România [The Association of Retired NCO of Romania], founded in 1926, focused on improving the material conditions of petty officers; ${ }^{51}$ Uniunea Ofițerilor de Rezervă [The Union of Reserve Officers], founded in 1924, led by General N. Rujinski, and initially composed of approximately four thousand members; ${ }^{52}$ and Asociația Generală a Ofițerilor de Rezervă [T.T.R.; The General Association of Reserve Officers], founded in $1933 \cdot{ }^{53}$ In addition, various other associations of officers, volunteers and decorated servicemen from the 1913 campaign and the Great War co-existed with these main organizations, such as: Asociația Regele Mihai I [The Association King Michael I]; Asociația Voluntarilor din Armata Română din Războiul pentru Intregirea Neamului [The Association of Volunteers in

49 Societatea Mărășești was dissolved in 1942 but reconstituted in 1945. See the Note of 28 May 1948, in Arhivele Naționale Istorice Centrale (hereby ANIC), Bucharest, fund Preșidenția Consiliului de Miniștri - Serviciul Special de Informații, 1920-1949, folder 32/1935-1948, 205-210.

50 The activity of the organization was monitored by the State Security since 1921. See Consiliul National pentru Studierea Arhivelor Securității, Fond Documentar, Dosar Cota SRI 2615 , online inventory, 69 .

$5^{1}$ The association had 1,500 members after the Second World War, undated report, likely from 1947, ANIC, Preșidenția Consiliului de Miniștri - Serviciul Special de Informații, 19201949, folder 32/1935-1948, 18-19.

52 Alexe Anastasiu, Congresul de la Londra al foştilor luptători FIDAC: 15-22 septembrie 1924: participarea delegaţiunii române: conferinţă ţinută la Ateneul Român la 11 Ianuarie 1925 (Bucuresti: U.O.R. Biblioteca, 1925), 4, 6.

53 See letter by T.T.R. general secretary G. Dinescu to Marshal Antonescu, from July 1943, in ANIC, Preșidenția Consiliului de Miniștri, 32/1935, 246-247. 
the Romanian Army in the War of National Unification]; Asociația Generală 'Barbăție și Credință' din România [The General Association Masculinity and Faith in Romania]; and Asociația Foștilor Luptători din Gărzile Naționale Române [The Association of Former Combatants of the Romanian National Guards] ${ }^{54}$ This complex landscape testifies to the associative nature and dynamism of the veterans' activism in the public sphere. But this fragmentation was also seen by various leaders as diluting the veterans' capacity to promote and defend their common interests. A first attempt at unification took place between May 31-June 1st 1927, when Uniunea Ofițerilor de Rezervă and five other smaller organizations assembled under the aegis of a newly-constituted federal union called Legiunea Română [The Romanian Legion] led by General Traian Moșoiu. The Legion's ambition was to group all veterans' associations into one big organization, following the model of the American and British Legions. Its promoters argued that some demands of all veteran associations 'are common and it will be easier to fulfill them through the Legion rather than through separate channels. ${ }^{55}$ To this end, the Legion attempted to facilitate the creation of bonds of solidarity among members, to cultivate feelings of patriotism and the cult of heroes, to militate for the veterans' rights, and to collaborate with similar organizations worldwide. ${ }^{56}$ Despite its efforts, the Legion did not manage to unify the major veteran associations. In 1934, three main organizations, Uniunea Națională a Foștilor Luptători, Uniunea Ofițerilor de Rezervă, and Societatea Mărășești united into a new federation called Regele Ferdinand I [King Ferdinand I] led by General Nicolae Rujinski. ${ }^{57}$ Just like its precursor, Legiunea Română, the new umbrella organization was only invested with arbitration and coordination powers.

Due to the heterogeneous nature of the body of veterans and their fragmentation in distinct associations, ex-servicemen did not act as a compact, collective political actor, but melted into the wider mass of voters. Without doubt, the veterans' war experience generated a common horizon of expectations; yet, their political options were also shaped by their age, class affiliation, education, and regional belonging. It is also important to note that no political party included special programmatic demands for the war veteran as a distinct category, but approached the issue of the veterans' reintegration in society within the context of the peasant and working class 'questions',

547 October 1947 report in Preșidenția Consiliului de Miniștri - Serviciul Special de Informații, 1920-1949, folder 32/1935-1948, 151-161.

55 Buletinul Uniunea Ofițerilor de Rezervă și în Retragere (November-December 1927), 34.

56 Buletinul Ofțterilor de Rezervă Secția Bihor 3 (1927), 29-30.

57 See 28 May 1948 note, ANIC, Preșidenția Consiliului de Miniștri - Serviciul Special de Informații, 1920-1949, folder 32/1935-1948, 206. 
which were socially relevant for the vast majority of the country's war combatants. Although we do not have distinct electoral statistics concerning the veterans, from a social-political perspective there is ground to assume that most peasant-veterans supported new populist organizations, most notably the Partidul Poporului [People's Party] and the Partidul Țărănesc [Peasant Party].

In the early 1920s, the People's Party, based on the charismatic cult of General Alexandru Averescu (1859-1938), showed effectiveness in rallying various segments of the national veterans' community around a common political project. The commander of the Second Romanian Army during the Great War, General Averescu emerged as the main architect of the successful resistance against the Central Powers in the summer of 1917 at Mărăști and Oituz. Following the end of military operations, Averescu negotiated the armistice leading to the completion of a separate peace with the Central Powers, as head of an ad-hoc government appointed by King Ferdinand (January-February 1918). After the signing of the Treaty of Bucharest by a new collaborationist government led by Alexandru Marghiloman, Averescu entered politics and started an assiduous public campaign for the reconstruction of the army, punishment for those guilty of Romania's military disaster and 'collaborationists' and the reorganization of the country's socio-political life. ${ }^{58}$ Unanimously regarded as one of Romania's leading war heroes, in the first postwar years the General attracted the consensus of the majority of former servicemen. He directed the spirit of the trenches and veterans' calls for political renewal towards a set of far-reaching reforms. Moreover, he pursued this program within the framework of the existing multi-party constitutional monarchy. The main vehicle for this new political project was the Liga Poporului [People's League], established on 3 April 1918 as an umbrella organization bundling together all political groupings interested in breaking up with the past and in starting a new course in political life. ${ }^{59}$ The League's main aims were the renewal of the political life of the country, universal suffrage and the political representation of minorities, the enactment of a radical agrarian reform, and administrative decentralization. ${ }^{60}$ The official mouthpiece of the League was the newspaper Indreptarea [Redress]; two additional journals were meant to disseminate the

$5^{8}$ On his discourse, see Alexandru Averescu, Răspunderile (Huși: Editura Ligei Poporului, 1918).

59 Alexandru Averescu, Uzurparea de la 4 iunie 1927 în lumina discursurilor şi declaraţiilor domnului general Averescu (Bucureşti, f.a.), 5 .

6o 'Actul de constituire a Ligii Poporului (3/16 aprilie 1918), accessed April 19, 2017, http://www.historia.ro/exclusiv_web/general/articol/ideologii-programe-politice -interbelic-ce-planuri-tara-aveau-marile. 
League's message among the peasantry, Gazeta Poporului [People's Gazette] and the working class, Muncitorul [The Worker]. After the war, Averescu's popularity had reached unprecedented heights, arguably turning him into 'the most popular politician at national level in Europe.' ${ }^{61}$ His prestige hence helped the League obtain 42.41 percent of the total number of votes cast in the March 1920 elections, ${ }^{62}$ thereby defeating the Liberal Party and forming a new government. Encouraged by this success, in April 1920 Averescu turned his cross-party League into a more conventional People's Party.

General Averescu therefore played a major political role in the stabilization of Romanian politics in the immediate postwar period. At a time when Greater Romania's political and administrative systems were in the making and thus lacked cohesion, the People's Party acted as a catch-all, national populist organization. Its heterogeneous electoral base was made up mainly of former combatants, peasants, and lower urban strata. In geographical terms, the People's Party gathered electoral support mostly in the Old Kingdom, yet it made inroads into the newly acquired provinces, as well. General Averescu was subject to a genuine charismatic cult, which brought together, 'in a mystical union', former combatants, the peasantry, and parts of the working class. ${ }^{63}$ The Conservative politician Constantin Argetoianu described the mystical, millenarian tinge that surrounded Averescu's cult in rural areas: 'Men kneeled, kissed his blue mantle, shook their heads, sighed deeply and whispered, "God, keep him well for our salvation!" ... Women did not dare to get closer, but they were all sobbing, pushing their children ahead to touch their savior!'64

The rule of People's Party (March 1920-December 1921) was characterized by major structural reforms meant to set Romania on new socioeconomical foundations, such as the monetary unification, financial reforms and the agrarian reform. Concerns for the status of war veterans figured centrally on the political agenda of the People's Party. As a former war combatant, General Averescu managed to capture the urge of political renewal born in the trenches, among peasant-soldiers, and to project it in the political life, acting as a spokesman of the veterans' corporate interests and aspirations. ${ }^{65}$ The former War Commander promoted laws meant to provide moral recognition as well

61 Constantin Argetoianu, Memorii, Volume v (Machiaveli, 1995), 114.

62 Marcel Ivan, Tabloul XIII, Evoluția partidelor noastre politice in cifre și grafice, 1919-1932: Studiu comparativ al rezultatelor oficiale ale alegerilor pentru Camera Deputaților din anii 1919-1932 (Sibiu: Krafft \& Drotleff, 1933), 59.

63 Politics and Political Parties in Roumania (London: International reference library Pub. Co, 1936), 190.

64 Constantin Argetoianu, Memorii, Vol. vi, Part VI (1919-1922), 46.

65 Politics and Political Parties, 190. 
as material support to the veterans. As in the prewar period, the main axis of the process of sacralizing politics was the cult of the fallen soldiers based on the triad Monarchy-Army-Church. ${ }^{66}$ The first step in this respect was taken by the establishment on 12 September 1919, by royal decree, of the Societatea mormintele eroilor căzuţi in război [Society for the Graves of the Fallen War Heroes], under the patronage of Queen Maria. ${ }^{67}$ One year later, the Averescu government adopted a comprehensive law regulating the commemoration of fallen soldiers at national level. ${ }^{68}$

The most important reform meant to provide material support for the veterans was the agrarian reform. The reform was implemented in 1920-1921 by way of four main distinct laws, for Bessarabia; Bukovina; Transylvania, Banat, Crişana and Maramureş; and a final one for the Old Kingdom. The law on Bessarabia did not contain stipulations for ex-servicemen (as the province fought the war as part of the Tsarist Empire) but granted land according to needs. ${ }^{69}$ The latter laws were conceived, however, as instruments of social justice meant to empower the soldier-citizen. They put forward a hierarchy of social categories entitled to land, privileging Romania's former combatants in the Great War but sanctioning the inhabitants who had collaborated with the enemy in wartime. The agrarian law for Bukovina granted priority access to land to families of fallen soldiers and to landless peasants who took part in the war, primarily to those who served as volunteers in the Romanian or allied army. Those who avoided conscription in 1919 or were sentenced for hostile actions against the Romanian army or the Romanian state were excluded from land acquisitions. ${ }^{70}$ Similarly, the land reform in the newly acquired provinces of Transylvania, Banat, Crişana and Maramureş granted

66 Iordachi, 'God's Chosen Warriors,' 341-346.

67 During its existence from 1919 to 1948 , the society managed to organize 118 cemeteries, 84 crypts, 13 mausoleums, 508 triptychs, the identification and arrangement of 529,713 graves, among which 72,870 abroad. See Ancerm, 'Expoziţia "95 de ani de la crearea Societăţii mormintele eroilor căzuţi în război",' accessed April 19, 2017, http://ancerm.ro/ expozitia-95-de-ani-de-la-crearea-societatii-mormintele-eroilor-cazuti-in-razboi/.

68 'Legea pentru cinstirea memoriei eroilor căzuţi,' Monitorul Oficial, no. 119 (2 September 1920), 4163-4164.

69 See mainly art. 33, 'LEGE de reformă agrară pentru Basarabia,' Decree No. 1.038, 11 March 1920, Monitorul Oficial No. 258, 13 March 1920, accessed 19 April, 2017, http://lege5.ro/ Gratuit/heztqnjy/decretul-nr-1036-1920-de-reforma-agrara-pentru-basarabia-votata-desfatul-tarii-la-27-noemvrie-1918-si-decretata-prin-decretul-dela-21-decemvrie-1918-cu-no3791-se-ratifica-cu-modificarea-art-1-12-14-

$70 \quad$ See art. 62. 'Legea nr. 3608/1921 pentru reforma agrară din Bucovina,' Monitorul Oficial 30 July 1921, accessed 19 April, 2017, http://lege5.ro/Gratuit/g42tgobz/legea-nr-3608-1921 -pentru-reforma-agrara-din-bucovina/3. 
land to war invalids, former soldiers who were heads of families, unmarried soldiers, and former volunteers in the Romanian or Allied armies, followed by married or unmarried peasants who did not participate in the war effort. ${ }^{71}$ The agrarian law for the Old Kingdom gave preferential access to land to: (1) former combatants in the 1916-1919 war; (2) former combatants in the 1913 Balkan War; (3) war widows; (4) small farmers deprived of land; (5) farmers with less than 5 hectares; and (6) war orphans. ${ }^{72}$ In addition, the Central House of Expropriation was authorized to sell plots to war invalids (art. 31). The law excluded war deserters from land property (art. 86.), while those who collaborated with the occupational regime were placed at the very bottom of the access list. To gather funds for redeeming the land, the government instituted a surcharge on the property of 'war profiteers' (art. 32).

Overall, the four land reforms transferred 2,776,401 hectares from large estates to small peasant properties, thus being the most radical expropriation of its kind in post-1918 Europe. ${ }^{73}$ This far-reaching redistributive process transformed Romania into a country of small plot owners. It laid the sociological foundations for the emergence of agrarian movements aiming to establish a Romanian 'peasant state'.

In addition to the agrarian reform, the government tried to alleviate social tensions in the industrial sector, too, by setting up the Ministry of Work and Social Protection (1920), with the aim of regulating labor relations. At the same time, Prime Minister Averescu reacted firmly against any anti-systemic protest movement, mobilizing the army to defeat the workers' general strike that took place on 20-28 October 1920 in response to new labor legislation. In May 1921, the Averescu government arrested the members of the newly established Romanian Socialist-Communist Party, who on the count of their open allegiance to Moscow voted for adherence to the Comintern. After a period of semi-legal existence, the Communist Party was outlawed in 1924, being charged with anti-national activities aimed at dismembering Greater Romania.

71 'Lege din 30 iulie 1921 pentru reforma agrară din Transilvania, Banat, Crişana şi Maramureş,' Monitorul Oficial, no. 93 (30 July 1921), accessed April 19, 2017, http://www.cdep.ro/pls/ legis/legis_pck.htp_act_text?idt=65850.

72 'Legea din 17 iulie 1921 pentru reforma agrară din Oltenia, Muntenia, Moldova şi Dobrogea (din vechiul regat),' Monitorul Oficial, no. 82 (17 July 1921), accessed April 19, 2017, http:// www.cdep.ro/pls/legis/legis_pck.htp_act_text?idt=65849.

73 Şandru, Dumitru. Reforma Agrară din 1921 în România (Bucureşti: Editura Academiei Republicii Socialiste România, 1975); David Mitrany, The Land and the Peasant in Rumania: The War and Agrarian Reform, 1917-1921 (New York: Greenwood Press, 1968), 189. 
TABLE 1 Distribution of the ownership of agrarian land in Romania, $1927^{74}$

\begin{tabular}{llcc}
\hline Category & Changes (ha) & Total surface (ha) & $\begin{array}{c}\text { Share of total } \\
\text { Agrarian land }\end{array}$ \\
\hline Up to 10 ha & $+2,776,401$ & $6,508,195$ & $81.43 \%$ \\
10-100 ha & - & 860,953 & $10.80 \%$ \\
Above 10o ha & $-2,776,401$ & 621,450 & $7 \cdot 77^{\circ}$ \\
\hline
\end{tabular}

SOURCE: DAVID MITRANY, THE LAND AND THE PEASANT IN RUMANIA: THE WAR AND AGRARIAN REFORM, 1917-1921 (NEW YORK, 1968), 189.

By overseeing the implementation of the electoral and land reforms, and by enhancing the legislation on welfare and social protection, General Averescu facilitated the veterans' socio-political reintegration in the political life of the country. At the same time, he contributed significantly to the 'domestication' of former servicemen. Specifically, Averescu's military prestige, his immense popularity and specific actions in government were instrumental in preventing a potential turn by the majority of veterans towards the far right or far left. Instead, the General helped channel Romanian former fighters' activism toward constitutionalism and loyalty to the dynasty. Nonetheless, once its immediate program was accomplished, the popularity of People's Party declined, dependent as it was on Averescu's personal charisma. The party returned to power in March 1926, after another crushing electoral victory, winning $52.09 \%$ of the total number of votes. ${ }^{75}$ After the People's Party's fall from power in June 1927, its electoral support waned, however, to $1.93 \%$ of the total number of votes in $1927,2.48 \%$ in 1928 , and $2.16 \%$ in $1932 .{ }^{76}$

The status of war veterans remained a constant preoccupation of Romanian politicians throughout the 1920s. In January 1922 the National Liberal Party of the Old Kingdom took the government over from the People's Party and led the country until March 1925, imposing its view on the nation's political life by way of a new constitution (1923) and a law on administrative organization (1925). The National Liberal Party treated the veterans' question as an important social issue. After the enactment of the agrarian and electoral reforms, efforts were directed toward social protection and welfare provision for those directly affected by the war. To this end, the government established

74 Source: David Mitrany, The Land and the Peasant in Rumania: The War and Agrarian Reform, 1917-1921 (New York, 1968), 189.

75 Politics and Political Parties, 191.

76 Ivan, Evoluția partidelor noastre politice, 59 . 
the Institutul pentru Invalizi, Orfani și Văduve [Iov; The Office for War Invalids, Orphans and Widows] made up of three branches: The General Association of War Invalids, The Protection of War Orphans, and The Widows of the heroes in the war $1916-1919 .{ }^{77}$ This office conducted a laborious activity on several pillars: old age pensions, educational grants for orphans, and welfare and medical assistance. ${ }^{78}$ The funds allocated by the state for the social protection of those social categories that suffered from the war grew more than three time in early to mid-1920s (see Table 2).

TABLE 2 Financial assistance to war invalids, orphans and widows, 1922-1926 (in Romanian Lei): $: 9$

\begin{tabular}{lllll}
\hline Year & $\begin{array}{l}\text { Via the general direction } \\
\text { of the office for war invalids, } \\
\text { orphans and widows }\end{array}$ & Via delegate societies & $\begin{array}{c}\text { Via other insti- } \\
\text { tution of social } \\
\text { protection }\end{array}$ & Total \\
\hline & Medical assistance & The General & Schools, \\
orphanages, and & \\
& & Association of War & Invalids; The Protection \\
other centers of & \\
& & of war orphans; The & social protection & \\
1922 & 4.554 .980 & Widows of the heroes & & \\
1923 & 3.500 .000 & in the war $1916-1919$ & & \\
1924 & 5.665 .000 & 48.936 .800 & 200.000 & 53.691 .780 \\
1925 & 11.400 .000 & 74.861 .250 & 393.800 & 78.755 .050 \\
1926 & 12.800 .000 & 123.000 .000 & 1.070 .000 & 129.735 .000 \\
& & 142.400 .000 & 970.000 & 154.770 .000 \\
& & 156.400 .000 & 1.170 .000 & 170.370 .000
\end{tabular}

SOURCE: PREȘIDENȚIA CONSILIULUI DE MINIȘTRI, ACTIVITATEA CORPURILOR LEGIUITOARE ȘI A GUVERNULUI DE LA IANUARIE 1922 PÂNĂ LA 27 MARTE 1926. DARE DE SEAMĂ ÎNFĂȚIȘATĂ DE D-L ION I.C. BRĂTIANU, PREȘEDINTELE CONSILIULUI DE MINIȘTRI (BUCUREȘTI; CARTEA ROMÂNEASCĂ, 1927), 356.

77 For the activity of this office in the general context of social policies in interwar Europe, see Silviu Hariton, 'Asumarea politicilor sociale de către stat în România: Cazul invalizilor, orfanilor și văduvelor de război (IOvR) după Primul Război Mondial,' in 'Studii de istorie social: Noi perspective,' ed. Constantin Iordachi and Alin Ciupală, Archiva Moldavice, Supliment 1 (2014), 115-140.

78 Preșidenția Consiliului de Miniștri, Activitatea Corpurilor legiuitoare și a Guvernului de la ianuarie 1922 până la 27 marte 1926: Dare de seamă înfățișată de d-l Ion I.C. Brătianu, Președintele Consiliului de Miniștri (București; Cartea Românească, 1927), 353-356.

$79 L e i$ is the currency of Romania. In 1929, the exchange rate was 167.20 lei for 1 U.s, dollar. 
In addition to social protection, the Liberal government also focused on the symbolic-ideological recognition of the veterans' contribution to the defense of the fatherland, though state-sponsored cultural policies. The cult of the fallen soldier, which served as a main axis of the process of sacralizing politics in the Old Kingdom, was greatly amplified in Greater Romania, being extended to the new provinces, as well, and used as an instrument of national unification. ${ }^{80}$ The main landmarks of this process were the official ceremonies surrounding the inauguration of the tomb of the unknown soldier in Bucharest, from 4 to 17 May 1923, the Day of the Ascension, in an impressive ceremony attended by the king, church hierarchies, army leaders, politicians and diplomats of allied countries; ${ }^{81}$ and the construction of the Mausoleum at Mărășești, initiated in 1923 and completed in 1938. Through these policies of social protection and symbolic-ideological recognition, the Monarchy and the government attempted to effectively coopt the veteran associations into the official 'culture of victory.'

The successful 'cooptation' of the veteran organizations by the state is also visible in their cooperation in matters of foreign policy. Romanian veterans developed strong ties to international organizations. Societatea Mărășești, in particular, collaborated with Confédération Internationale des Associations de Mutilés et d'Anciens Combattants [CIAMAC; International Confederation of Associations of Disabled and Ex-Servicemen], an organization which attempted to mobilize ex-servicemen from victor and defeated countries on international reconciliation and domestic welfare issues. The most important ties were developed with the Fédération Interallié des Anciens Combattants [FIDAC; InterAllied Federation of Ex-Servicemen], an organization of veterans from victor countries only that also aimed at promoting European peace and old soldiers' welfare. On 9-13 May 1926, Uniunea Ofițerilor de Rezervă hosted Colonel Fred Abbot, chairman of FIDAC's Propaganda Committee. Most importantly, in 1928 and 1938, two annual FIDAC meetings took place in Bucharest. ${ }^{82}$ These ties were encouraged by the Romanian state, who was interested in mobilizing FIDAC in the defense of the Versailles Peace Treaties, in general, and of Romania's borders, in particular. On 5 September 1926, Uniunea visited the Polish Reserve Officers' Congress in Warsaw, thus cementing the comradeship

$80 \quad$ For overviews, see Bucur, Heroes and victims; and Silviu Hariton, War Commemorations in Inter-War Romania (PhD diss., Central European University Budapest, 2014).

81 For a detailed report of the ceremony, see 'Ostașul Necunoscut,' Foaia Diecezana XxxvıII, no. 10 (7 May 1923), 3-6.

82 Buletinul Uniunea Ofițerilor de Rezervă - Sectia Bihor 1 (1926), 25-26; Buletinul Uniunea Ofțerilor de Rezervă - Sectia Ilfov 9-10 (1926), 69-75. 
between Romanian and Polish veterans. ${ }^{83}$ On the occasion, Uniunea's delegation stressed the threat to peace posed by Bulgarian paramilitary groups' incursions in neighboring countries, ${ }^{84}$ proposing an official condemnation of those attacks by both organizations. ${ }^{85}$ On 12 December 1927, during a special meeting of the FIDAC's governing council, the Romanian delegation supported the Yugoslav representatives' requests for stronger links between FIDAC and the League of Nations. Additionally, it sanctioned recent revisionist press campaigns, like the one promoted by Lord Rothermere to advocate changes in Hungary's borders. ${ }^{86}$

\section{Financial Crisis, Political Polarization and Veterans' Activism: The 1930s}

In late 1920 and early 1930s, the political activism of the veterans, and of the peasantry in general, was mainly absorbed by Partidul Național-Țărănesc [NPP; The National-Peasant Party]. This Party was established in 1926 through the fusion between the National Party in Transylvania (founded in 1881 in AustriaHungary and previously known as the Romanian National Party of Transylvania and Hungary) and the Old Kingdom's Peasant Party. The Peasant Party was created in 1918 by a medley of devoted activists originating from the rural intelligentsia and well-to-do strata of the peasantry and was led by Ion Mihalache, a demobilized captain in the Great War. The origins of the Peasant Party were intertwined with those of the People's League; they both expressed the anger and frustration of the peasant-soldiers concerning Romania's series of military defeats in the Great War, corruption and lack of social justice. As compared to the League, the Peasant Party went further in its demands: it advocated extensive land reforms, decentralization, and support for independent farmers. Political adversaries accused the peasantists of 'radicalism', arguing they were plagued by a 'sectarian' class attitude and that they ignored the harmonization of social interests at national level. It should be noted, however, that the peasantry constituted at the time about $80 \%$ of the Romanian population, and thus also encompassed, in all likeness, the majority of veterans. Given the fact that the Peasant Party obtained strong electoral results in rural areas, it can be safely inferred that this Party managed to attract the support of many peasantveterans. In 1919, taking advantage of the electoral abstention of the People's

83 Buletinul Uniunea Ofițerilor de Rezervă și în Retragere 11-12 (1926), 19-20.

84 Buletinul Uniunea Ofițerilor de Rezervă - Secția Ilfov 9-10 (1926), 88-89.

85 Buletinul Uniunea Ofițerilor de Rezervă și în Retragere 11-12 (1926), 36.

86 Buletinul Uniunea Ofițerilor de Rezervă - Sectia Bihor 4 (1927), 43. 
League, the Peasant Party scored a stunning electoral victory, with $46 \%$ of the total number of votes. In the ensuring period, the party had to share its electorate base with the People's Party, but it remained nevertheless highly popular, with $12.5 \%$ of the national votes in 1920 and $18.5 \%$ in $1922 .{ }^{87}$ The 1926 merger of the Peasant Party and the National Party gave birth to Romania's second mass democratic party, the NPP. After a series of mass rallies against the Liberals, NPP won the 1928 elections with a share of $77.76 \%$ of the total votes and dominated politics in the period 1928-1933. Its rule could not live up to the high public expectation, however, being gradually marred by the economic crisis, allegations of corruption, and party instability.

The 'failure' of NPP's rule led to major transformations in Romania's political life. First, following his coronation in June 1930, King Carol II emerged as a major political player, deliberately undermining political parties and the parliamentary system, with the aim of establishing his personal rule. Second, the world economic crisis hit hard Romania's economy in 1929-1932, leading to a dramatic decrease in the standard of living. Third, and in close relation to the previous two points, support for mainstream political parties was eroding in favor of new, radical movements of change. Although social assistance for veterans and their descendants remained a constant governmental preoccupation, the economic crisis brought about a major setback in welfare policies, leading to a crisis in the relationship between veterans and the state.

In reaction to a governmental initiative to curtail social benefits of war veterans (such as free railway passes), the Federation of War Invalids, Widows and Orphans convoked a great assembly on 12 April 1930 in Bucharest, attended by circa two thousand persons. ${ }^{88}$ The participants demanded the restoration of lost benefits, the strict observance of the law on the social protection of the veterans, and the prolongation of the war orphans' pension until they finished university studies, and not simply until they reached the age of twenty-one. ${ }^{89}$ The Federation planned to end the congress with a public march in the center of Bucharest but the demonstrators were soon blocked by the army (see Picture 1 below). ${ }^{90}$ This action led to violent clashes with the authorities in

87 Ivan, Evoluția partidelor noastre politice, 10.

88 'Îndrunirea invalizilor din sala Dacia,' Curentul III, no. 801 (13 April 1930), 4.

89 'Marea Adunare a Invalizilor,' Curentul III (12 April 1930), 7.

9o The recent online publication of this picture generated a debate over the identity of the speaker on the improvised podium: many viewers argued that the crowd animator was no other than Corneliu Zelea Codreanu, the leader of the Legion of 'Archangel Michael'/ the Iron Guard. This hypothesis was rightfully refuted by more informed viewers, who pointed out that the dressing style and allure of the speaker do not correspond to that of the Legion's 'Captain'. It is nevertheless significant to note that, in the public historical 


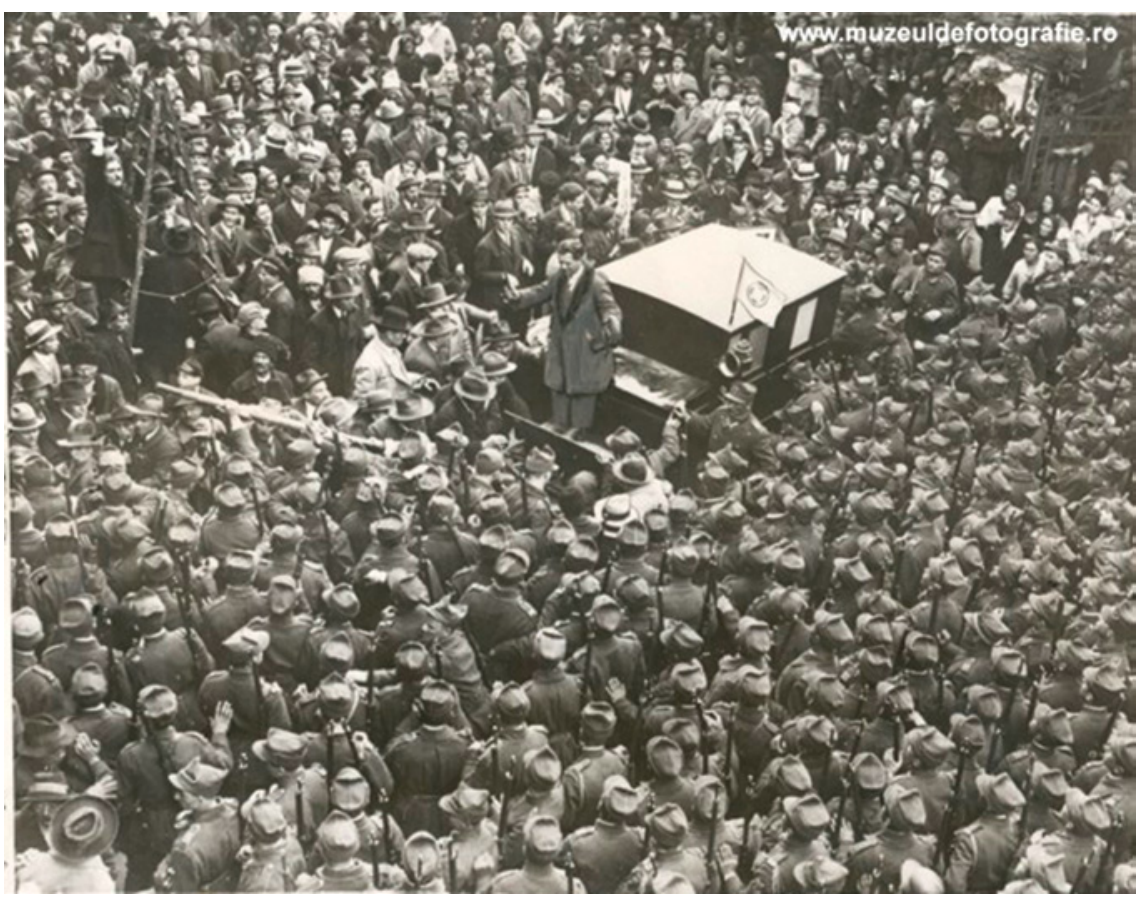

ILLUSTRATION 2 'A street scene in Bukarest, Romania, recently, when soldiers, war mothers and invalids staged a demonstration protesting against the official policy of the government toward those who had suffered losses in the world war. Many clashes with the police were reported and twenty-eight arrests made. Several were also reported injured, though none of these were invalids. (The Associated Press).'

SOURCE: HTTP://WWW.MUZEULDEFOTOGRAFIE.RO/2010/07/

VETERANII-IES-IN-STRADA/

front of the Bucharest police commissioner's office and of the parliament, until the invalids were dispersed by fire-fighters with water-jets. In their defense, circa 2,000 nationalist students organized a march of solidarity that ended in front of the Prime Minister's house, hoping to capitalize on the political radicalization of the veterans. ${ }^{91}$ An official communique of the Ministry of the

imagination, Codreanu's political activism and the radicalization of the veterans are closely associated. In other words, one would 'expect' the Captain to be present at the scene. See comments on Alex Galmeanu, 'Veteranii ies in strada - Update! - Corneliu Zelea Codreanu?' Weblog Muzeul de Fotografie, accessed April 19, 2017, http://www.muzeuldefotografie.ro/2010/o7/veteranii-ies-in-strada/.

91 'Dureroasele incidente din cursul zile de eri,' Curentul III, no. 801 (13 April 1930), 8. See also Ioan Scurtu, 'Studiu Introductiv,' in Ideologie și formațiuni de dreapta în România, 
Interior blamed the political opposition, and in particular the communists, for inciting the war invalids. ${ }^{92}$

The government's intervention made a terrible public impression, generating a public outcry. An official communique of the Central Committee of the Federation condemned 'with all its energy and indignation the brutal intervention of the authorities, who provoked scandal and brutalities unknown until today.' It also condemned some politicians' insinuations that the veterans were manipulated in their actions by 'speculators or communists. ${ }^{93} \mathrm{~A}$ number of military associations, such as the Cercul Subofițerilor de rezervă [Circle of Reserve Sub-officers] and the Asociația Ofițerilor în Rezervă și Retragere [Association of Reserve and Retired Officers] expressed their solidarity to and support for the cause of war invalids, widows and orphans. Reactions in the press were highly critical of the ill-conceived governmental action, as it contradicted the symbolic-ideological consensus of the postwar period. The leading journalist Pamfil Șeicaru called the incident 'a day of shame for our entire people. ${ }^{94} \mathrm{He}$ accused the government of not sending an official representative at the Federation's assembly, of not facilitating their dialogue with the authorities, and of mobilizing the army against the war veterans. More generally, Șeicaru blamed the entire political class for politicizing the war memory and the cult of the fallen soldier, arguing that 'the memory of the war has become only a simple rhetorical theme. ${ }^{95}$ In reality, however, the government neglected real war heroes, while providing tangible rewards to former 'deserters, traitors, and spies. ${ }^{96}$ Facing this concerted campaign, the government reconsidered its position. On 13 April 1930, a delegation of the Federation led by General Mărășescu presented its demands to Prime Minister Iuliu Maniu. The government pledged to preserve the existing social assistance provisions, including railway passes, without any cuts; it also allocated an additional 35 million lei in support of certain categories of war invalids. ${ }^{97}$ The next day, the Senate voted a new law on army recruitment.

1927-1931, ed. Ioan Scurtu, et. al (București: Institutul Național pentru Studiul Totalitarismului, 2000), 25, 37 .

92 'Dureroasele incidente,' 8.

93 'Comunicatul federației I.o.v.,' Curentul III, no. 802 (14 April 1930), 7.

94 Pamfil Șeicaru, 'Ziua Tristeței,' Curentul III, no. 802 (14 April 1930), 1. See also Ion Dumitrescu, 'Lepădații victoriei,' Curentul III, no. 804 (16 April 1930), 7.

97 'Invalizii la Primul Ministru,' Curentul III, no. 802 (14 April 1930), 7. 
During the parliamentary debates, General Prezan, himself a hero of the Great War, appealed to the government 'never to mobilize the army against the war invalids or those who served on the front,' pointing out that 'a war invalid is a symbol of sacrifice for the fatherland. ${ }^{98}$ Opposition deputies accused the improper management of social protection funds, marred by corruption and incompetence. ${ }^{99}$ The Minister of Interior Alexandru Vaida-Voevod presented openly his regrets, and was forced to admit that in the twelve years that had passed since the Great War 'the question of the veterans has not been solved. 100

The financial crisis was gradually overcome in mid to-late 1930s. To ensure a balanced national coverage of the social needs of the war veterans, the activity of the Office for War Invalids, Orphans and Widows was re-organized in four regional branches: Bucharest, Chișinău, Iași, and Cluj. In 1936, these branches managed eight shelters for war orphans and six shelters for war invalids. All over the country there were twenty-two institutions of social assistance for war veterans (seven in Moldova, six in Muntenia, five in Transylvania, and two in Bessarabia and Bukovina), with 795 places and a total budget of 13,135, 747 lei. ${ }^{101}$

Despite these efforts, the (temporary) crisis of the welfare state affected the social pact between the veterans and the Romanian state, highlighting the formers' 'culture of entitlement' that had developed gradually since 1878 . The deterioration of the veterans' standard of living and the growing ideological polarization in Romania's political life led to the politicization of certain veteran associations on the basis of a radical, anti-establishment political platform. At the same time, many far right organizations conducted intensive recruitment campaigns specifically targeting former veterans. Radicalized veterans were absorbed by the fascist Legiunea 'Archangelul Mihail' [Legion of 'Archangel Michael', hereafter the Legion] but also by other kindred organizations. Established in 1927, the Legion was part of the second European wave of radicalization to fascism (the first one witnessing the advent of Fascism to power in Italy but also the failure of the 1923 Hitler-Ludendorff-Putsch in Bavaria). ${ }^{102}$ The Legion

98 'Senatul a votat legea armatei,' Curentul III, no. 802 (14 April 1930), 7.

99 'Dezbaterile parlamentare,' Curentul III, no. 802 (14 April 1930), 7.

100 'Dureroasele incidente,' 8.

101 See 'Asistența I.o.v.', in Instituțiile de asistență socială și de ocrotire: Rezultatele recensământului Instituțiilor de asistență socială și de ocrotire din 1 ianuarie 1936 (București: Editura Institutului Central de Statistică, 1938), 99.

102 For works on the Legion of Archangel Michael, see selectively Francisco Veiga, La Mística del Ultranacionalismo: Historia de la Guardia de Hierron. Rumania, 1919-1941 (Bellaterra: 
had important affinities with certain programmatic elements of the veterans' associations, including its name (see the abovementioned Legiunea Română, also established in 1927), the emphasis on the internal consolidation of Greater Romania through an educational campaign of moral character-building, and the cult of the fallen soldiers. Yet, the Legion was not rooted in the movement of veterans as was the National Fascist Party in Italy; its backbone was the student movement, especially in the disputed territories of Bukovina, Transylvania and Northern Moldavia. ${ }^{103}$ In generational terms, most of the early adherents of the Legion were pupils and students born around the turn of the century. As such, they had been unable to participate to the war effort but were determined to prolong the national struggle in peace time, against 'internal enemies'. ${ }^{104}$ The most important leaders of the movement attended military schools (see the case of the movement's charismatic leader, Corneliu Zelea-Codreanu) or underwent voluntary military training (see the case of Ion Moța, Codreanu's main collaborator), and promoted the militarization of politics. ${ }^{105}$

The Legion was organized as a semi-clandestine organization. Its members received a paramilitary training based on army instruction, hierarchy and values. An order by Codreanu dated 5 September 1933 instructed all Legionaries to procure themselves green uniforms and a revolver with a legal permit or a blade weapon. ${ }^{106}$ The Legion was not exclusively a youth movement, but welcomed adult males as well. The veterans or retired military who attained the rank of sergeant or corporal and possessed firearms and valid firearm permits were a special recruitment target of the Legion. The Legionary movement

Universitat Autònoma de Barcelona, 1989); Armin Heinen, Die Legion 'Erzengel Michael' in Rumänien: Soziale Bewegung und politische Organisation: Ein Beitrag zum Problem des internationalen Faschismus (Munich: R. Oldenbourg Verlag, 1986); Constantin Iordachi, Charisma, Politics and Violence: The Legion of the 'Archangel Michael' in Inter-war Romania (Trondheim : Norwegian University of Science and Technology, 2004); Michael Mann, Fascists (Cambridge: Cambridge University Press, 2004); Roland Clark, Holy Legionary Youth: Fascist Activism in Interwar Romania (Ithaca: Cornell University Press, 2015).

103 For an early analysis of the student roots of the Legion in the context of the process of unification in Greater Romania, see Irina Livezeanu, Cultural Politics in Greater Romania: Regionalism, Nation Building and Ethnic Struggle, 1918-1930 (Ithaca, London: Cornell University Press, 1995).

104 Constantin Iordachi, 'De la credinţa naţionalistă la credinţa legionară: Palingenezie romantică, militarism şi fascism în România modernă,' in Fascismul European, 1918-1945: Ideologie, Experimente Totalitare și Religii Politice, ed. Constantin Iordachi (Cluj: Institutului pentru Studiul Minorităților Naționale, 2014), 365 .

105 See Iordachi, 'God's Chosen Warriors,' 337-338.

106 ANIC, Fund Direcția Generală a Poliției, 4/1933, 9, $9 v$. 
prized these potential followers' military training and expertize and the social prestige they usually enjoyed in their communities. This converting effort did not include, however, former combatants of Jewish origin: the Legion displayed a rabid anti-Semitism and disputed the patriotism and wartime credentials of Romania's Jews.

The Legion's policy of active recruitment resulted in an influx of veterans into its ranks. ${ }^{107}$ It is important to note, in this respect, that former servicemen were part of all major collective leadership organs or assisting organizations of the Legion, including the Senate and the 'Committee of the One Hundred' gathering the movement's sympathizers. Additionally, the Legion tried to enroll serving soldiers into its ranks, but with limited success. ${ }^{108}$

Although the input of former combatants into the Legion was significant, it was never as large as to transform the Legion from a student movement into a proper veterans' organization. Moreover, the political relations between the Legion and radicalizing veterans' organizations were not characterized only by collaboration, but also by rivalry. The trajectory of Asociația 'Cultul Patriei' [Association 'Cult of the Fatherland'] is illustrative in this respect. The Association was established in December 1926 under the leadership of the philosopher and university professor Marin Stefănescu, fan ex-serviceman and war invalid. The association was joined by numerous retired generals, while its honorary president was the decorated war hero General (Marshall after 1930) Constantin Prezan. Cultul Patriei aimed at promoting patriotic education based on traditional moral values, and at undertaking cultural activities meant to defend and consolidate the Romanian nation-state. ${ }^{109}$ In the early 1930, the association underwent a process of radicalization, acquiring an overt political character, enrolling radical politicians from other parties, and developing a militant nationalist platform. ${ }^{110}$ This orientation set it on a collision course with the government, the gatherings of Cultul Patriei often degenerating into

\footnotetext{
107 For an overview of local veterans' fascist activism in the interwar period, see Ioan Scurtu, ed., Totalitarismul de Dreapta in Romania: 1919-1927 (Bucarest: Institutul National pentru Studiul Totalitarismului, 1996), 373-375; Dana Beldiman, 'Armata Română si mișcările de dreapta și extremă dreapta, 1921-1937,' Arhivele Totalitarismului 9, no. 32-33 (2001), 14-19.

108 See Dana Beldiman, Armata și Mișcarea Legionară 1927-1947 (București: Institutul Național pentru Studiul Totalitarismului, 2002).

109 ANIC, Preșidenția Consiliului de Ministri, 32/1935-1948, 84-85. For the association's activities promoting the cult of the fallen soldier, see 'Un an de la Înființarea Asociației ,Cultul Patriei', Cultura Poporului viı, no. 210 (20 November 1927), 1.

110 ANIC, Preșidenția Consiliului de Miniștri, 32/1935-1948, 85.
} 
street fights with the authorities. ${ }^{111}$ In reaction, on 5 April 1932 the government dissolved the Association, portraying its activities as 'harmful to the public order and the general interests of the State' on the ground that 'they went well beyond its statutory regulations' as they touched upon 'issues with political and economic implications.'112 Marshall Prezan, the honorary president, supported the government's act, repudiating the association's later activities. ${ }^{113} \mathrm{In}$ early 1933, following a verdict of the High Court of Cassation, Cultul Patriei was allowed to re-emerge, and it continued its process of radicalization. ${ }^{114}$ The association conducted an assiduous proselytizing campaign, building ties with other veterans' organizations and managing to enrol reserve officers, priests and students. ${ }^{115}$ Cultul Patriei attempted a closer alliance with the Legion of 'Archangel Michael', but the negotiations with Corneliu Zelea Codreanu were unsuccessful. Instead, Cultul Patriei entered another rival right-wing political coalition entitled 'The Constitutional Front'. Animated by General Nicolae Rădescu, this 'Front' included the People's Party, the National Liberal Party's Gheorghe Brătianu, Grigore Forțu's Blocul Românesc pentru Salvarea Patriei [Romanian Block for Salvaging the Country] and Cruciada Romanismului [Crusade of Romanianism], a new far-right organization led by the Legionary dissident Mihai Stelescu (who would end up being assassinated by the Legion in July 1936). ${ }^{116}$ In March 1935, Cultul Patriei established its own youth section, 'with a purely nationalist character,' led directly by Ștefănescu. ${ }^{117}$ Cultul Patriei thus increasingly turned into a vehicle for Ștefănescu's political ambitions to become an apostle of the nationalist youth, distinct from Codreanu and his movement. ${ }^{118}$ Forțu and Ștefănescu proved meteoric players on the Romanian political scene, however, while Codreanu's movement was to have a strong political impact in the late 1930s and the beginning of the 1940s.

111 Ibidem, 87.

112 Ibidem, 96-97.

113 Constantin Schifirneț, 'O concepţie originală despre filozofia românească: Marin Ştefănescu,' Atheneum, 10 June 2008, accessed April 19, 2017, http://www.atheneum. ca/constantin-schifirnet/o-conceptie-originala-despre-filozofia-romaneasca-marinstefanescu. Originally published as Constnatin Schifirneț, 'Studiu Introductiv,' in Marin Ştefănescu, Filosofia Românească (București: Historia, 2008).

114 ANIC, Preșidenția Consiliului de Miniștri, 32/1935-1948, 86.

115 Ibidem, 88.

116 Ibidem, 89-90.

117 Ibidem, 107.

118 For the cult of personality around Ștefănescu, see Schifirneț, 'O concepţie originală despre filozofia românească.' 


\section{From Demobilization to Radicalization: Romania and Italy in Comparison}

This article has explored patterns of demobilization and political activism of ex-servicemen in post-1918 Romania. It has been argued that, overall, Romanian political elites were remarkably successful in mobilizing the population for the war effort, in keeping soldiers in arms until as late as 1920, and in enacting a smooth demobilization. In the interwar period, the Romanian state managed to coopt the veterans' associations into the official 'culture of victory' through a combination of welfare entitlements and symbolic politics centered on the triad Army-Church-Monarchy. This alliance was challenged only in early to late 1930 s. On the one hand, the state partially faltered on its social protection commitments, under the burden of the economic crisis; on the other hand, the growing dissatisfaction with traditional parties and the ideological polarization of Romania's political system stimulated the radicalization of certain segments of the veterans' community.

To better grasp the specificities of this case study, the concluding section of the article advances a comparison to similar processes that took place in Italy. This juxtaposition is instructive because the two cases exhibit a peculiar set of similarities and differences. During the long nineteenth century, Romania and Italy underwent an almost congruent process of nation-state building, based on the Risorgimento principle of adding new historical regions to a statebuilding 'core' represented by the Old Kingdom of Romania and by PiedmontSavoy (see the union of Moldavia and Wallachia in 1859 and the annexation of Dobrudja to Romania in 1878; and, respectively, the 1861 unification of most of the Italian peninsula under the House of Savoy, and the annexation of Venetia and the former Papal States to the Kingdom of Italy by 1871). In the 188os, both countries entered into a long-term alliance with Germany and Austria-Hungary but eventually entered the First World War on the side of the Entante (Italy in 1915, Romania in 1916), and fought mainly against Austria-Hungary in order to complete their process of nation-state building. Both countries suffered painful defeats on the front, but they ultimately emerged victorious from the war as part of the Entente forces. Yet, their postwar development was largely divergent. The Italian case differs from Romania in two main respects: firstly, although during the War the political establishments in both countries were divided over the foreign policy path to be followed, Italy experienced wider political cleavages within its armed forces and home front. Secondly, after the conflict the Italian elites failed to reintegrate veterans into the status quo, thereby facilitating the seizure of power by Mussolini's Fascist movement and ensuring that veterans' associations would be harnessed to an emerging totalitarian State project. 
In both countries, the national issue was intertwined with pressing social questions, among which the most important was the peasant one. Romania enacted a first land reform in 1864, yet after the turn of the century the agrarian system experienced a new, aggravating crisis, leading to massive peasants revolts. Romania's prewar social tensions in rural areas were mirrored in Italy by similar cleavages. Italian peasants faced persistent land shortages as well, especially as late-nineteenth century anti-feudal laws had failed to create a class of rural smallholders. Unlike Romania, the Italian state did not enact an agrarian reform, but managed to hold the peasantry in check by repressing rural uprising. In addition, in order to alleviate social tensions in the countryside, a small-town 'political class' at local level encouraged the mass emigration of peasants and even managed to make money off the rural migrants it helped leave the country. ${ }^{119}$

The Great War strained Italy's political and social fabric more than it did in the Romanian case. It heightened social tensions within the Army, due to widespread misgivings about the necessity of the conflict, a pronounced divide between senior officers and troops and the exceptionally strict discipline imposed upon soldiers. ${ }^{120}$ Four years of total conflict engendered other destabilizing legacies: peasant conscripts grew expectations of land reform; ${ }^{121}$ several revolutionary interventionist volunteers and Arditi shock troopers developed a violent nationalist ethos; ${ }^{122}$ the political 'witch-hunts' and militarization processes that took place on the home front deepened pre-existing cleavages within Italian society. ${ }^{123}$

After the war, while Romanian elites managed to successfully demobilize many local veterans through a blend of deterrence, welfare and politics of symbols, the Italian Liberal governments failed, on the whole, to implement a

119 Martin Clark, Modern Italy, 1871-1982 (London, New York: Longman, 1984), 12-21, 31-34, 161-167.

120 Brian Bond, War and Society in Europe, 1870-1970 (Oxford: Oxford University Press, 1986), 124-125; Paul Corner, Giovanna Procacci, "The Italian Experience of "Total” Mobilization, 1915-1920,' in State, Society and Mobilization in Europe during the First World War, ed. John Horne (Cambridge: Cambridge University Press, 1997), 229-232.

121 Emilio Lussu, Marcia su Roma e Dintorni (Milano: Einaudi, 1974), 2.

122 Emilio Gentile, Le Origini dell'Ideologia Fascista (Bologna: Il Mulino, 1996), 153-190.

123 Angelo Ventrone, 'Fascism and the Legacy of the Great War,' in The Legacies of Two World Wars: European Societies in the Twentieth Century, ed. Lothar Kettenacker and Torsten Riotte (New York: Berghahn, 2011), 92-97. 
similar strategy, mainly due to the uncooperative attitude of important sectors of civil society but also their own mismanagement of the issue. As regards the economic reintegration of the veterans, in 1919 the Orlando government alienated returning soldiers with its poor handling of relief for discharged troops. This estrangement was subsequently reinforced by the government's widely uneven benefit provisions. ${ }^{124}$ The elections of the same year, which polarized parliament between liberals, popolari and socialists, made it increasingly difficult to devise and implement payback politics for former servicemen. ${ }^{125}$ Moreover, the Italian veterans' community ended up being split between three major category associations, the patriotic ANC, the Catholic Unione Nazionale dei Reduci di Guerra [UnR; National Union of War Survivors] and the socialist Lega Proletaria Mutilati, Invalidi, Reduci, Orfani e Vedove di Guerra [MIrov; Proletarian League of War Disabled, Invalids, Survivors, Orphans and Widows], undermining this community's chances of asserting its rights. Disagreements between these associations contributed to the failure of an organic land reform, which was only in part compensated by the forcible occupation of uncultivated estates by peasant combattenti. ${ }^{126}$ It can be claimed therefore that the polarization of Italian veterans prevented the fulfilment of the rural masses' aspiration to land, which had long predated the War. ${ }^{127}$ The abovementioned ad-hoc land occupations, while apparently successful in the short run, were in many cases repealed once the Fascists rose to power.

The political demobilization of veterans was also unsuccessful, both in terms of coercion and symbolic integration. The Italian Liberal State, unlike the Romanian one, was not especially well entrenched in terms of its capacity to wield political control. ${ }^{128}$ Additionally, it was difficult for the establishment to derive much legitimacy from the kind of 'mutilated victory' that emerged from the Paris Peace Conference. ${ }^{129}$ Most importantly, a divided civil society created conflicting interpretations of the wartime sacrifices; that divide

\footnotetext{
124 Giorgio Rochat, L'esercito Italiano da Vittorio Veneto a Mussolini (Bari: Laterza, 1967), $13-38$.

125 Giovanni Sabbatucci, I Combattenti nel Primo Dopoguerra (Bari: Laterza, 1974), 271-281.

126 Sabbatucci, I Combattenti nel Primo Dopoguerra, 175-98; Gianni Isola, 'Socialismo e Combattentismo: la Lega Proletaria, 1918-1922,' Italia Contemporanea 141 (December 1980), 14-15.

127 Clark, Modern Italy, 209-210.

128 Mann, Fascists, 95 .

129 Horne, 'Beyond Cultures of Victory and Defeat?' 219.
} 
fostered further strife. ${ }^{130}$ In this situation, unsurprisingly, many combattenti's attachment to existing institutions sapped, while active minorities on the Left and the Right turned to paramilitary activism. Two major transnational events further polarized the Italian veterans' community, hampering the emergence of a 'shared framework of core political assumptions' ${ }^{131}$ as a prerequisite for a resilient culture of victory. Firstly, the Russian revolution galvanized the large Italian Socialist Party - and some of the veterans connected to it - into assuming a revolutionary stance towards the middle classes and the nation-state, while also radicalizing rightist combattenti into action against left-wing civil society. ${ }^{132}$ Secondly, Prime Ministers Nitti and Giolitti's hostility to Gabriele D'Annunzio's occupation of Fiume/Rijeka contributed to the delegitimization of the Liberal elite in the eyes of nationalist former fighters. ${ }^{133}$

Traditional political actors underestimated the danger posed by veterans' paramilitarism and therefore committed numerous 'tactical' mistakes. Thus, in 1919 Liberal Prime Minister Nitti sped up discharge operations at a time when the military authorities were voicing their concerns that veterans might be co-opted by revolutionary forces, especially in the case of the Arditi. ${ }^{134}$ The socialists, in the same year, antagonized right-wing veterans with their calls for revolution and refused to forge an alliance with the moderate ANC, despite the latter's overtures. ${ }^{135}$ They also failed to develop a cohesive combat organization that would deter the budding Fasci di combattimento from campaigning through violence. ${ }^{136}$ In 1921, Liberal Prime Minister Giolitti underestimated the effects of the Fascist movement's growth - including the strengthening of paramilitary tendencies among rightist veterans - and allowed it to take hold

130 See, for instance, the panoply of meanings attached to the Caporetto defeat, along the Left-Right political spectrum, in Wilcox, 'From Heroic Defeat to Mutilated Victory,' 48-49.

131 Ziemann, Contested Commemorations, 13. Ziemann refers to the absence of this kind of framework in Weimar Germany, but his assessment would appear to be pertinent also to the Italian case study.

132 Isola, 'Socialismo e Combattentismo,'12-16; Gerwarth and Horne, 'Bolshevism as Fantasy,' 44-45.

133 Thomas Row, 'Italy in the International System, 1900-1922,' in Liberal and Fascist Italy, ed. Adrian Lyttelton (Oxford: Oxford University Press, 2002), 102-104.

134 Michael A. Ledeen, 'Italy: War as a Style of Life,' in The War Generation, ed. Stephen R. Ward (New York: Kennikat Press, 1975), 108-109.

135 Sabbatucci, I Combattenti nel Primo Dopoguerra, 78-86, 346.

136 Eros Francescangeli, Arditi del Popolo: Argo Secondari e la Prima Organizzazione Antifascista, 1917-1922 (Roma: Odradek, 2000), 42-45, 85-107. 
in Central and Northern Italy to weaken the socialist party. ${ }^{137}$ Ultimately it was Fascism that exploited the radicalization of various Arditi and other sections of the veterans' community to the fullest, by using them to seize power in 1922. Mussolini then arguably managed to demobilize the majority of Italian combattenti by applying a 'triad' of deterrence, welfare and symbolic integration of the kind his Liberal predecessors had failed to assemble.

The Fascist mixture of incentives and constraints differed from the one deployed in Romania. With regard to the extent of State-imposed deterrence, it should be noted that Mussolini had come to power at the head of a paramilitary movement, amid a latent civil war. Consequently, after 1922, the articulation of any independent political message by veterans - even by former fighters with unquestionable patriotic credentials - became increasingly difficult. Not only were MIROV and UNR disbanded, but ANC was subjected to a governmentappointed triumvirate in $1925 .{ }^{138}$ Ultimately, ANC veterans could claim a public role only by conforming to the Fascist regime's codification of the meaning of the War experience ${ }^{139}$ and disseminating fascist ideology, including notions such as the need for perpetual warmongering to preserve the vigor of the Italian people. These propagandistic values contradicted the founding principles of their category organization. ${ }^{140}$

In granting material benefits to old soldiers, the Fascist regime was influenced by the compromises it reached with the Italian economic establishment,

137 Emilio Gentile, E fu subito Regime: Il Fascismo e la Marcia su Roma (Bari: Laterza, 2012), 24-26.

138 Sabbatucci, I Combattenti nel Primo Dopoguerra, 373.

139 By 1926 the Fascist regime aimed to assert that the Great War had been purely a crusade for nationalist expansion; left-wing interventionist 'delusions' that the War had been a struggle for the promotion of democracy in Italy and abroad, were to be considered as nonsense, see the official ANC monthly magazine Italia Augusta, May 1926, editorial.

140 In the immediate aftermath of the War, ANC had embraced Wilsonianism and international pacifism. The Regime, however, almost from the outset envisioned this veterans' organization as a mouthpiece for expansionist propaganda. For instance, in 1926, government-appointed ANC executive Nicola Sansanelli held a speech in Genova, warning an audience of former servicemen that the time was ripe for the younger generations to get their own chance at 'achieving glory'. It was the duty of the combattenti to help these youngsters fulfill their wish, see internal communication number 3858 , dated 26 February 1926, from the folder 1852, dossier 528080, in the fund Archivi degli Organi e delle Istituzioni del Regime Fascista - Segreteria Particolare del Duce, Carteggio Ordinario, at the Archivio Centrale di Stato, in Rome, 2. 
including large landowners. Therefore, unlike in Romania, no comprehensive land reform took place. Instead, Fascism confirmed the acquisition of some of the estates occupied by veterans in the early postwar years, but also reverted the property of many others. Mussolini later found a partial alternative to reform by 'displacing' the old soldiers' 'land hunger' onto terrains reclaimed through drainage and irrigation, such as the Pontine Marshes. ${ }^{141}$ As for welfare, the concession of benefits became arguably more politicized than in the Liberal era, as it was officially managed by ANC, which in turn was supervised by the Partito Nazionale Fascista [National Fascist Party]. ${ }^{142}$

Finally, as for symbolic integration, Fascism managed to satisfy many patriotic veterans' wish to see their wartime sacrifice extolled, chiefly by including these former fighters in its mass rituals. It can be argued nonetheless that, due to its ideological prescriptions, Mussolini's regime saw patriotic veterans less as custodians of the nation and more as a perfectible prototype of the New Fascist Man. Therefore, a peculiar culture of victory was imposed by the Partito Fascista onto the country, which, like the Romanian one, honored the wartime accomplishments of veterans and insisted on the need to work for the reconstruction of the nation. Unlike the latter culture, however, Italian Fascism celebrated numerous non-veterans - noticeably the youths that after the War had fought in the Fasci di combattimento - as paragons of martial prowess and patriotic self-abnegation. ${ }^{143}$ In the 1930s, the Fascist regime began linking national consolidation with imperialist expansionism. ${ }^{144}$ As a consequence,

141 Clark, Modern Italy, 268-271; Roger Absalom, 'The Peasant Experience under Italian Fascism,' in The Oxford Handbook of Fascism, ed. R.J.B. Bosworth (Oxford: Oxford University Press, 2010), 6-27.

142 An example of the Fascist party's collaboration with ANC with regard to welfare provision and job placement can be found in the propaganda volume Associazione Nazionale Combattenti: Adunata e Congresso Provinciale, Cervia, 19 Maggio 1929 (Ravenna: Società Tipo-Editrice Ravennate e Mutilati, 1929), 1-24.

143 By promoting cultural events like the Mostra della Rivoluzione Fascista, Fascism turned dead squadristi youths and veterans into 'the regime's saints', see Mimmo Franzinelli, 'Squadrismo,' in The Oxford Handbook of Fascism, ed. R.J.B. Bosworth (Oxford: Oxford University Press, 2010), 10.

144 On 4 November 1937, during an official ceremony in Rome, ANC president Amilcare Rossi handed a message to the families of the volunteers who had fallen in the Fascist Spanish campaign. The message explained that this campaign was necessary to preserve both the 'fruits of Vittorio Veneto' and the Fascist African Empire. See Il Messaggero, 5 November 1937. 
while Great War veterans did preserve a prominent rank in the Fascist 'hierarchy of national sacrifice', they had to increasingly share this position with the servicemen from the Fascist wars of the 1930s and World War Two.

After the political turmoil of the early postwar years, the Fascist seizure of power thus brought about a significant redefinition of the relationship between the old soldiers' community and the State. Specifically, veterans' organizations underwent a sensible reduction of political agency and were turned into mouthpieces for Fascist propaganda. Economic payback politics appear to have been implemented according to such criteria as one's political conduct during the biennio rosso and fidelity to the Regime, rather than the nature of one's wartime service. Due to these factors, the Italian case would appear to differ significantly from the Romanian one. In the former, the veteran identity survived in a much more blatant form, while at the same time being constrained in a narrower variety of sanctioned forms of expression. Moreover, veterans' political activism possibly remained more diffuse in Italy than in Romania, but was also more regulated due to the increasingly totalitarian nature of the local political system.

The growing influence of the Fascist regime's political priorities over the activism of Italian veterans can be also noticed in the domain of international relations, as it shaped the transnational activities of $A N C$ and the main war invalids and mutilates association, the Associazione Nazionale Mutilati e Invalidi di Guerra [ANMIg; The National Association of War Disabled and Invalids]. From the mid-1920s to the late 1930s, these associations were stable members of the FIDAC. Through their involvement in the congresses and meetings organized by FIDAC, ANC and ANMIG undoubtedly helped foster a 'panEuropean' ${ }^{\prime 145}$ culture of victory. To mention a few of the contributions made by Italian veterans to the aforementioned culture, it should be highlighted that the ANC delegation at the 1924 London Congress supported the rightfulness of Greater Romania's acquisition of Besarabia after the War. ${ }^{146}$ Moreover, ANC executive Nicola Sansanelli and ANMIG general secretary Giovanni Baccarini held important posts in FIDAC, the former becoming president in 1927 and the latter vice-president in 1929. To a certain degree, therefore, Italian veterans played a stabilizing role in interwar European relations. This conclusion

\footnotetext{
145 Eichenberg and Newman, 'Introduction,'12.

146 Alexe Anastasiu, Congresul dela Londra al Foștilor Luptători F.I.D.A.C., 15-22 Septembrie 1924 (Bucuresti: Biblioteca U.O.R., 1925), 20-21.
} 
is further suggested by ANM IG's participation, in 1925, in the Geneva founding congress of CIAMAC. Additionally, in 1936 ANMIG president Carlo Delcroix - at the time also holding the presidency of FIDAC - advocated the creation of a common forum between veterans from all European states.

Nevertheless, as acknowledged by Martina Salvante, ${ }^{147}$ the combattenti's transnational activism ended up being subjected to the directives of the Fascist government and therefore became increasingly functional to the regime's agenda of persecuting internal enemies and undermining the postwar international system. For instance, ANC's censure of communism at the 1925 FIDAC Congress in Rome helped legitimize, in the eyes of the international public opinion, Mussolini's concomitant repression of the Italian Left. Furthermore, in the 1930s the Duce's increasingly resolute pursuit of empire and alliance with other revisionist nations required of the Italian veterans to help destabilize the European culture of victory to which they had contributed in the previous decade. At the 1931 FIDAC Congress in Prague an Italian delegate undercut a proposal by Romania, Poland and Yugoslavia that reaffirmed the intangibility of the Peace Treaties. Additionally, during the rest of the decade Italy withdrew from cooperation with CIAMAC and in 1938 ended up leaving FIDAC, thereby contributing to the latter's demise.

Overall, the combattenti's collaboration with international veterans' organizations can be characterized as more conditional than the one enacted by the Romanian luptători. Moreover, Italian veterans showed a comparatively weaker commitment to the preservation of the postwar status quo. That attitude was undoubtedly influenced by the combattenti's deep-rooted dissatisfaction with the unresolved territorial issues that affected north-Eastern Italian borders, as suggested by the continuous quarrels that took place within FIDAC gatherings between Italian and Yugoslav delegations. ${ }^{148}$ Nonetheless, ANC and ANMIG's eventual support for Fascist revisionism and imperialism should not be regarded as inevitable. After all, until 1923, ANMIG was clearly committed to preserving international peace through cooperation with international veterans' organizations and the League of Nations. ${ }^{149}$ The consolidation of

147 Martina Salvante, 'The Italian Associazione Nazionale Mutilati e Invalidi di Guerra and Its International Liaisons in the Post Great War Era,' in The Great War and Veterans' Internationalism, ed. Julia Eichenberg and John Paul Newman (New York: Palgrave Macmillan, 2013), 162-183.

148 Salvante, 'The Italian Associazione Nazionale Mutilati e Invalidi di Guerra,' 164.

149 Ibidem, 169. 
Mussolini's regime led to a gradual but resolute change in ANC and ANMIG's relationship to the transnational veterans' movement. By rigidly subordinating the veterans' associations to the regime's official policy, silencing antifascist veterans and, at a later stage, pursuing a set of imperialist wars, the Duce impressed a qualitative change on the transnational activism of Italian former fighters. 